\title{
A zenei teljesítményszorongás: prevalencia, kialakulás, társuló zavarok és személyiségvonások, kezelési lehetóségek
}

\author{
DOBOS BIANKA \\ Szegedi Tudományegyetem, Bölcsészettudományi Kar, \\ Neveléstudományi Doktori Iskola, Szeged
}

(Beérkezett: 2018. november 13.; elfogadva: 2019. március 10.)

\begin{abstract}
A társas kapcsolatok hiánya és a szociális funkciók romlása, az alacsony énhatékonyság és ennek következtében a csökkent életminőség a szorongásos zavarok gyakori velejárói. A társas környezetben tapasztalt szorongás nemcsak a vonásszorongással és a tökéletességre való törekvéssel függ össze, hanem a pszichológiai védőfaktorok hiányával is. Annak ellenére, hogy a lámpaláz hazánkban is igen elterjedt, a pedagógusok csak kis mértékben, vagy egyáltalán nem tudnak tanácsot adni a kezelést vagy a tünetek enyhítését illetően. Nemzetközi szinten dinamikusan nő a lámpaláz iránti érdeklődés, bővül a zenészek körében alkalmazott terápiás lehetőségek száma, míg hazánkban csak elvétve találunk olyan tanulmányokat, amelyek említenék ezt a témakört. Ezt a hiányt szeretném pótolni a jelen tanulmánnyal, amelyben bemutatom a zenei teljesítményszorongás háttértényezőit, a társuló mentális zavarokat és azokat a kezelési módszereket, amelyek hatékonyságát már zenészek körében is igazolták. A szakirodalmi áttekintés alapján a zenei teljesítményszorongás minden korosztályban és hangszercsoportban előforduló jelenség. Tünetei a specifikus fóbiával mutatnak hasonlóságokat, fokozott szociális félelem esetén azonban felmerülhet a szociális szorongás gyanúja. Más szorongásos zavarokhoz hasonlóan gyakrabban fordul elő nők körében. Kialakulásának hátterét egy pánikszerú negatív érzelem képzi, amely kondicionálás útján asszociálódik a zenei teljesítményhelyzettel. Protektív faktorként tekinthető az énhatékonyság-érzés és a vonásszintú tudatosság, ezek hiányában gyakran jár együtt depresszióval és perfekcionizmussal. A társuló zavarok miatt kezelése komplex, azonban megfelelő terápia és gyógyszeres kezelés pozitív változásokat eredményez. Az oktatási intézményekben jelenleg nagy szükség lenne olyan előadói készségfejlesztó kurzusokra és szakmai programokra, amelyek tájékoztatásra adnának lehetőséget a zenei teljesítményszorongást és annak kezelését illetően.
\end{abstract}

Kulcsszavak: lámpaláz, zenei teljesítményszorongás, szociális fóbia, szociális szorongás zavar, perfekcionizmus, énhatékonyság

\footnotetext{
* Levelezési cím: Dobos Bianka, SZTE BTK Neveléstudományi Doktori Iskola, 6722 Szeged, Petófi sgt. 30-34. E-mail: dobos.bianka@gmail.com
} 


\section{Bevezetés}

A zenészek által gyakran tapasztalt koncert előtti szorongás csökkenti a zenei teljesítményt, negatívan hat a jóllétre, hosszútávon pedig csökkenti az életminőséget (Bonde, Juel, \& Ekholm, 2018; Wijsman \& Ackermann, 2018). A leggyakrabban idézett definíció szerint a zenei teljesítményszorongás „tartósan fennálló aggodalom érzete az észlelt és/vagy ténylegesen csökkent, társas környezetben előforduló előadói készségek romlása miatt, ami nem vezethető vissza a személy adottságaira, gyakorlására és felkészülési szintjére" (Salmon, 1990, 3. o.). Zenei stílustól függetlenül a lámpaláz leginkább a szólóban történő előadások alkalmával fejti ki negatív hatását (Nicholson, Cody, \& Beck, 2014; Papageorgi, Creech \& Welch, 2011; Topoğlu, Karagülle, Keskin, Abacigil, \& Okyay, 2018). Koncert napján az állapotszorongás és a pulzusszám szignifikánsan magasabb egy koncertmentes naphoz képest (Kenny, 2004); nem meglepő tehát, hogy a magas zenei teljesítményszorongás kevesebb előadói tevékenységgel jár együtt (Paliaukiene és mtsai, 2018), fellépés közben pedig alacsony az észlelt énhatékonyság. Több kutatási eredmény is alátámasztja, hogy a zenei teljesítményszorongás tünetei növelik a kiégés kockázatát (Bernhard, 2010), hosszútávon pedig a fellépések elkerüléséhez vezetnek (González, BlancoPiñeiro, \& Díaz-Pereira, 2017). Egy spanyol vizsgálatban a megkérdezett zenészek 19\%-a már gondolkodott azon, hogy erős szorongása miatt talán jobb lenne, ha elhagyná a zenei pályát (Orejudo, Zarza-Alzugaray, \& Casanova, 2018).

\section{Prevalencia}

Előfordulását tekintve a zenei teljesítményszorongás azonos mértékben gyakori gyermek (Nusseck, Zander, \& Spahn, 2015; Patston, \& Osborne, 2016), középiskolás (Fehm, \& Schmidt, 2006; Thomas, \& Nettelbeck, 2013), illetve felnőtt zenészek körében (Nielsen és mtsai, 2017; Robson \& Kenny, 2017). Legtöbbször 15-40\% azon zenészek aránya, akik zenei teljesítményszorongással küzdenek (Fishbein, Middlestadt, Ottati, Straus, \& Ellis, 1988; Nielsen és mtsai, 2017), de egyes vizsgálatokban ez a szám a $80 \%$-ot is meghaladja (Topoğlu és mtsai, 2018; Zakaria, Musib, \& Shariff, 2013). Gyermekekkel végzett vizsgálat alapján 3-4 éves korban kevesebb a koncertet megelőző anticipációs szorongás, ha korábban már játszottak hangversenyen (Boucher \& Ryan, 2010); illetve kevesebb szorongásos tünetet tapasztalnak azok, akik hétéves kor előtt kezdik meg zenei tanulmányaikat (ZarzaAlzugaray, Orejudo, Casanova, \& Aparicio-Moreno, 2017). Ryan (2004) vizsgálatában a fiúknak több szorongásos tünetük volt fellépés során, azonban a lányok szívritmusa fellépés előtt lényegesen magasabb volt. A 15-19 
éves kamaszokat vizsgálva nem mutatkozott nemi különbség a szorongás mértékében, azonban 10\%-uk a lámpalázat egy rendkívül negatív hatásként jellemezte a zenei pályán (Fehm \& Schmidt, 2006). A gyerekek többsége szerint szorongásuk legfontosabb oka a közönség előtt történő hibázás lehetősége (Ryan, 1998).

\section{A zenei teljesítményszorongás kialakulásának modelljei}

Egy potenciálisan veszélyes helyzetbe kerülve az emberi szervezet kétféle módon reagálhat: megküzd a helyzettel, vagy valamilyen módon elmenekül. Barlow $(2002,219$. o.) a "fight or flight" vészreakciót valódi veszélynek nevezi („true alarm”), amely során a félelem és a fenyegetettség érzése egy veszélyes helyzet miatt okkal keletkezik. Ezzel szemben a hamis veszély (pánik) egy fenyegetó esemény hiányában jön létre („false alarm”). A zenei teljesítményszorongás szintén kétféle reakciót válthat ki: 1) a szorongás optimális mértéke nem akadályozza az előadót; 2) a szorongás az előadás rovására megy, a személy így képességein alul teljesít (Biasutti \& Concina, 2014). A hamis veszély váratlanul éri a személyt, ami leginkább egy "spontán, ok nélküli” pánik, vagy intenzív félelem (Barlow, 2002, 220. o.). A szomatikus tüneteit túlértékelve a személy ugyanúgy reagál egy negatív életeseményre, mintha az egy valódi fizikai veszélyforrás lenne (Barlow, 2002, 223. o.). Vajon milyen tényezók járulnak hozzá a "false alarm”, avagy a hamis veszély érzetének kialakulásához? Barlow (2002, 221-232 o.) érvelése szerint ennek a védelmi funkciónak fóbb okai lehetnek:

- Genetikai tényezók: A false alarm (pánik) a szorongástól eltérő módon öröklődik. Okozhatja a stressz által kiváltott neurobiológiai hyperreaktivitás, ami védelmi funkcióként pánikrohamot vált ki.

- Szeparációs szorongás: A gyermekek szeparációs szorongása később hozzájárulhat a hamis veszélykialakulásához (Barlow, 2002). Egy retrospektív vizsgálatban a szeparációs szorongás zavar erős rizikófaktor volt a pánikzavar és a depresszió kialakulásában (Lewinsohn, Holm-Denoma, Small, Seeley, \& Joiner, 2008). Szociális fóbia hátterében szintén gyakoriak a gyermekkorban átélt traumatikus élmények, illetve a szülóktól való szeparáció (Bandelow és mtsai, 2004).

- Szorongásra való érzékenység: A pánik tüneteire való válaszunk nagyban függ attól, hogy szüleinktól milyen viselkedési mintát láttunk abban a helyzetben, amelyben a pánik tünetei megjelentek. Amennyiben a szülők túlértékelik a szomatikus tüneteket, a gyermek erős szorongással reagál a specifikus tüneteire.

- Negatív életesemény (stressz, mint előzmény): Különböző szorongásos zavarok megjelenése előtt a személyek többsége egy vagy több negatív 
életeseményt idéz fel. Green és munkatársainak (2010) vizsgálatában a kedvezőtlen családi körülmények (pl.: szülő mentális betegsége, érzelmi elhanyagolás, fizikai és/vagy érzelmi bántalmazás) a felnőttkorban jelentkező mentális zavarok közel 30\%-át magyarázták.

- Alapszorongás: A magas „baseline” szorongás nagyban hozzájárul a pánik megjelenéséhez (Barlow, 2002). Leginkább akkor keletkezik pánikroham, amikor az alapszorongás szintén magas.

Barlow $(2000,2002)$ szorongásmodellje három olyan összetevőt tartalmaz, amelyek hozzájárulhatnak egy szorongásos zavar kialakulásához: 1. általános biológiai sérülékenység (öröklött); 2. általános pszichológiai sérülékenység (váratlan negatív életeseményekkel való megküzdés képtelenség); 3. specifikus pszichológiai sérülékenység (különböző tanulási folyamatok által a szorongás asszociálódik bizonyos környezeti ingerekkel). Barlow (2000) érvelése szerint a harmadik pontban tárgyalt specifikus sérülékenység jelenléte által létrejöhet a pánikzavar vagy a specifikus fóbia. A személy vonásszorongása (általános biológiai sérülékenység), a környezet magas elvárásai és alacsony támogatottság (általános pszichológiai sérülékenység), illetve a gyakori versenyhelyzetek kiválthatnak olyan pszichológiai, viselkedéses és kognitív válaszokat, amelyek jellemzőek a zenei teljesítményszorongásra (Kenny, 2006). Egy fenyegető helyzetben a személy figyelme a saját érzéseire irányul, aminek következtében nő a szomatikus tüneteinek intenzitása és fokozódik a szorongás. A szociális kiértékelés hatására a szomatikus tünetek asszociálódnak az észlelt fenyegetéssel (Kenny, 2006), az előadás közben megjelenő katasztrofizáló gondolatok pedig gátolják a koncentrációt. Az eddigi fogalmakat és elméleteket integrálva alkotta meg modelljét Kenny (2010), amelyben leírja a zenei teljesítményszorongás kialakulásában és fennmaradásában szerepet játszó tényezőket (1. ábra). A modell Barlow (2002) szociális fóbia kialakulásának modelljére épül. A szürke színnel jelölt rész ábrázolja azt a kondicionálási folyamatot, amelynek eredményeképpen létrejön a szorongásos élmény, ezáltal a generalizált szociális fóbia. Ha a személyre jellemző a specifikus pszichológiai sérülékenység, akkor fennáll a nem-generalizált szociális fóbia kialakulásának lehetősége (Kenny, 2010, 441. o.). Ebben a modellben a Barlow (2002) által jellemzett valódi és hamis veszély egy pánikszerú negatív érzelem vagy egyéb reakció, amely kondicionált válasszá alakult egy stresszhelyzetre. A zenei teljesítményszorongás kialakulását megelőzően a hangversenyek során átélt pozitív érzelmek eredményeképpen a szorongásos élmény csökkenhet. Amennyiben a csökkent teljesítmény észlelt vagy valós, az ezt követó negatív érzelmek és az önértékelés a szorongásos élményhez társulhatnak, és újabb veszélyeket (alarm) válthatnak ki egy olyan kört létrehozva ezáltal, amelyben a zenei előadás már önmagában kondicionált veszélyeket fog kiváltani még azelőtt, hogy az előadás elkezdődne (Kenny, 2010, 443. o.). 
A zenei teljesítményszorongás elkerülése érdekében elsősorban meg kell akadályozni azt, hogy az előadás összekapcsolódjon a szorongásos élménynyel; el kell kerülni azt a folyamatot, amely során az észlelt veszély szorongásos választ kondicionál az előadáshoz (Kenny, 2010). A korábban tapasztalt negatív élmény megismétlődése a jövőben érzelmi tanuláshoz vezet, amely során az inger (zenei előadás) különböző negatív érzelmekkel telítődik, a negatív érzelmi reakciók pedig kondicionált félelmi válaszokká alakulnak át (Kenny, 2010). Egyes zenészeknél az intenzív teljesítményszorongás ellenére az előadás minősége nem sérül, vagyis az észlelt hamis veszély által létrejöhet negatív kognitív és érzelmi válasz, ennek azonban nincs hatása a zenei előadásra. A sikeres előadások - a pozitív eredmény ellenére kiválthatnak veszélyérzetet, amely ismétlődés által tanult válasszá alakul (Kenny, 2010, 444. o.). A specifikus pszichológiai sérülékenységgel együtt ezek elindíthatják a specifikus szociális fóbia kialakulását, amely összekapcsolódik a zenei teljesítménnyel. Ez a sérülékenység tehát erősen asszociálódik az előadással anélkül, hogy az előadás bármiféle negatív következménynyel járna. Kenny (2010) szerint ilyen esetekben feltételezhető egyéb szorongásos zavar jelenléte, nem pedig az, hogy valódi veszély által jön létre a zenei teljesítményszorongás.

\section{A zenei teljesítményszorongáshoz gyakran társuló zavarok}

\subsection{Szociális fóbia}

Más szorongásos zavarokhoz hasonlóan a szociális fóbia gyakrabban fordul elő gyermekkorban, különösen lányok körében (Canals, Voltas, HernándezMartínez, Cosi, \& Arija, 2018; Coelho \& Romão, 2018; Essau, Lewinsohn, Lim, Ho, \& Rohde, 2018). A 12 hónapos és az életprevalencia értékek különböző országokban 2,4\% és $4 \%$ között (Stein és mtsai, 2017), míg specifikus fóbia esetén az életprevalencia 3\% és 15\% között mozog (Eaton, Bienvenu, \& Miloyan, 2018). Az érintettek 80\%-a 18 éves kor előtt tapasztalja meg az első tüneteket (Koyuncu és mtsai, 2015), azonban csak az esetek 20\%-ában fordulnak szakemberhez (Crome és mtsai, 2014). Jellemző a negatív megítéléstől való erős félelem és az alacsony önbizalom (Perczel-Forintos \& Kresznerits, 2017). Képalkotó eszközök segítségével kimutatható a szociális szorongásnál jelen lévő neurotranszmitter anyagcserezavar (Doruyter, Dupont, Stein, Lochner, \& Warwick, 2018). A szülők mentális egészsége és nevelési stílusa szintén hatással lehet a tünetek korai megnyilvánulására. Lieb és munkatársai (2000) kapcsolatot találtak a szülók szociális fóbiája és gyermekeik szociális fóbiája között. Vizsgálatukban a szülők depressziója, túlzott gondoskodása vagy elutasító szülői magatartása szintén összefüg- 
gést mutatott a 14-17 évesek szociális szorongásával. Az érintettek többségénél a nyilvános beszéd okozza a legtöbb szorongást (Ruscio és mtsai, 2007), de minél több szociális helyzetre terjed ki a félelem, annál súlyosabb hatást fejt ki a mentális egészségre (Peyre és mtsai, 2016).

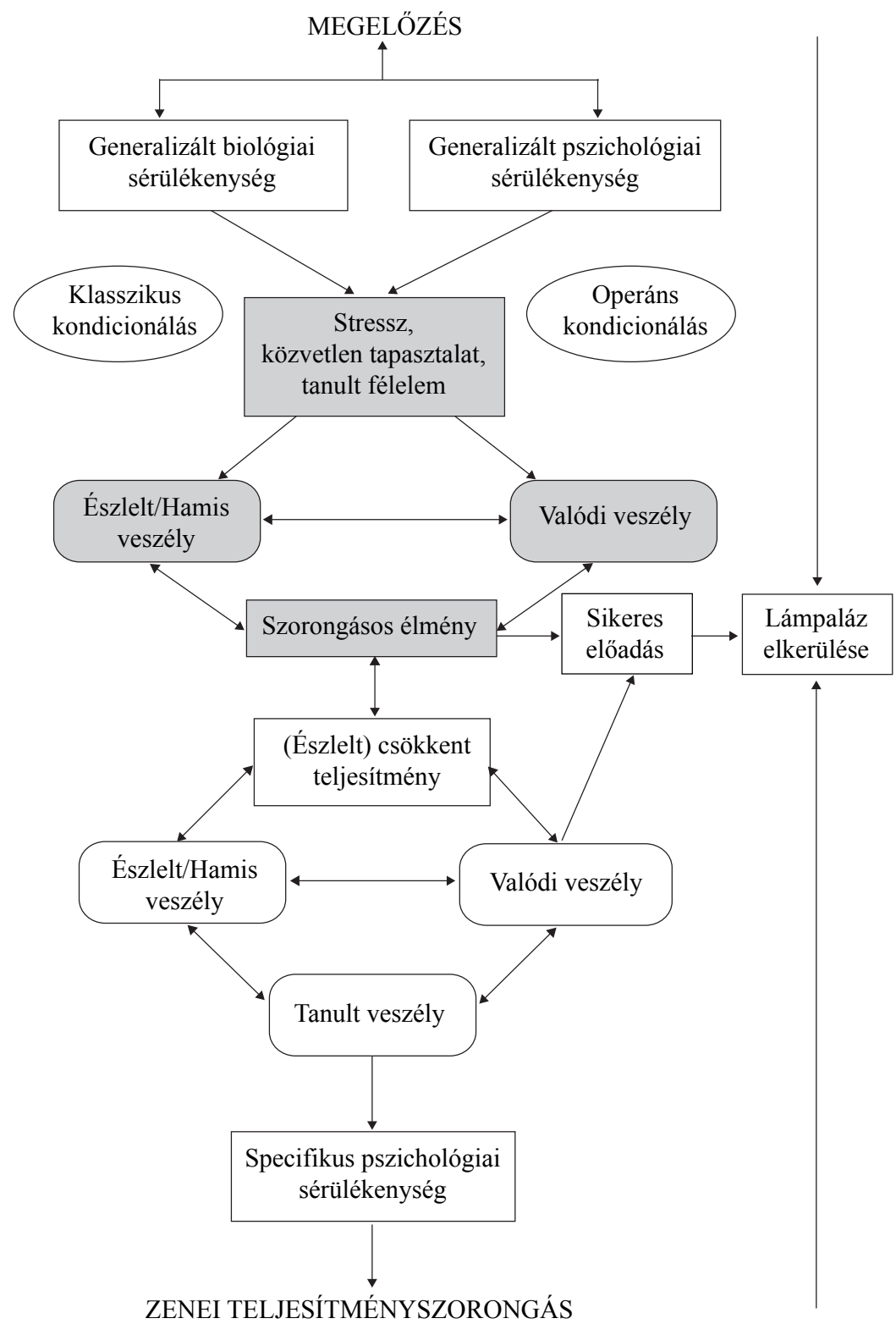

1. ábra. A zenei teljesítményszorongás kialakulása, fennmaradása és elkerülése (Kenny, 2010, 442. o. nyomán) 
A Mentális zavarok diagnosztikai és statisztikai kézikönyvének (DSM-5; American Psychiatric Association [APA], 2013) a szociális fóbiára vonatkozó kritériumai sok szempontból egyeznek a zenei teljesítményszorongás tüneteivel (Nicholson és mtsai, 2014). Egyes kutatók szerint zenei teljesítményszorongás lehet egy specifikus fóbia (Kenny, 2006; Nicholson és mtsai, 2014). Specifikus fóbia esetében más társas helyzet nem okoz félelmet (APA, 2013, 203. o.). Jelentős különbség a kettő között, hogy míg a szociális fóbiánál gyakori a biztonságkereső viselkedés (Piccirillo, Dryman, \& Heimberg, 2016), addig a zenei teljesítményszorongás nem jár feltétlenül hangversenyek kerülésével, sőt, egyes zenészek erős szorongás ellenére is kitartanak a koncertek mellett. Kenny (2010) szerint a helyzettel való sikeres megküzdés az elhivatottság és a zene iránti alázat eredménye lehet.

Brazil zenészek 19\%-ának volt szociális szorongása, ami jelentősen meghaladta a populáció $4 \%$-os előfordulási gyakoriságát (Andrade és mtsai, 2012). A vizsgálatok gyakori tárgyát képezi a szociális fóbiához társuló szerhasználat (Blumenthal, Taylor, Cloutier, Baxley, Lasslett, 2019; Grant és mtsai, 2015). Conway és munkatársainak (2016) vizsgálatában az alkoholés szerfogyasztás különösen magas volt a szorongásos zavarral kezelt kamaszoknál. Annak ellenére, hogy az alkohol hatása csökkenti a szorongást, a személy önmagáról alkotott percepciója még ekkor sem változik, vagyis alkohol hatása alatt is kritikus magával szemben (Stevens, Cooper, Bantin, Hermann, \& Gerlach, 2017). Zenészek szerfogyasztási szokásait vizsgálva több tanulmány is rávilágított már a gyakori béta-blokkolók, és kisebb mértékben a szorongáscsökkentő, illetve antidepresszáns gyógyszerek használatára (Barbar, Crippa, \& Osório, 2014; Dobos \& Pikó, 2017; Fishbein és mtsai, 1988; Kenny, Driscoll, \& Ackermann, 2012). Egy friss kutatásban a gyógyszerek közül leggyakoribb volt a béta-blokkoló (12\%), ezután következett a gyógyszerek (béta-blokkolók, benzodiazepinek) használata más gyógyhatású készítményekkel (6,3\%), majd a különböző mértékú alkoholfogyasztás (1,7\%). A nem, a hangszer típusa és a szerhasználat típusa között nem mutatkozott szignifikáns összefüggés, azonban a nők körében gyakoribb volt a szerhasználat (Orejudo és mtsai, 2018).

Korábbi kutatások kimutatták, hogy szociális fóbiánál gyorsabb az érzelemfelismerés, ha a személyek egy negatív arckifejezést látnak (Du Rocher \& Pickering, 2019; Torro-Alvesés mtsai, 2016). Osório és munkatársainak (2017) vizsgálatában a zenészek boldog arckifejezésekre adott hoszszabb reakcióideje összefüggést mutatott a zenei teljesítményszorongással. Sabino és munkatársai (2018) azt vizsgálták, hogy zenészek körében vajon kimutatható-e hasonló jellegzetesség érzelemfelismerés terén. Az eredmények szerint a magas lámpalázzal rendelkező személyeknél a félelem felismerése volt a leggyorsabb; legtöbbször a boldogságot tükröző arckifejezés felismerésekor hibáztak, de általánosságban véve lassabb volt az érzelem- 
felismerésük a kontrollcsoporthoz képest (Sabino és mtsai, 2018). Gyermekeknél a félelmet sugárzó arckifejezésekre való fokozott odafigyelést a szülők szorongása, vagy kritikus nevelési attitúdje is kiválthatja (James, Owens, Woody, Hall, \& Gibb, 2018). Meyer és Kroner (2017) vizsgálatában a fiatal felnőttkorban jelentkező szorongás összefügg a gyermekkorban diszfunkcionálisnak érzett nevelési stílussal és a szülők túlzott aggodalmával. A bántalmazó, agresszív szülők gyermekei szorongóbbak és kevésbé önállóak, azonban a szülői támogatás hatására a szorongás csökken (Gouze, Hopkins, Bryant, \& Lavigne, 2016).

A zeneoktatásban résztvevő gyermekeknél a tanulmányok sikerességében szintén meghatározó a családi háttér és a szülők elvárásai (McPherson \& Davidson, 2002, 2006). Zenész gyermekekkel végzett vizsgálatok eredményei szerint a zenei élményt és a tanulási folyamatba való bevonódást segíti a szakmailag hozzáértó szaktanár, aki személyiségével alkalmazkodik a diák növekvő igényeihez (Davidson, Moore, Sloboda, \& Howe, 1998), emellett szintén fontos, ha a diák érzi a szülők és a tanárok közötti pozitív kapcsolatot (McPherson \& Davidson, 2006). Creech (2007) vizsgálatában a gyerekek jobban élvezték a zenét, nőtt az énhatékonyság-érzésük és a motivációjuk, amikor a szüleikkel meg tudták beszélni a gyakorlással kapcsolatos teendőiket, illetve, ha a szüleik megbeszélték gyermekeik haladását a zenetanárral és megfelelő környezetet biztosítottak a nyugodt otthoni gyakorláshoz.

Creech és Hallam (2010) 6 és 18 év közötti, hegedún tanuló diákoknál vizsgálta a szülókkel és a tanárokkal való interakciók hatását az önbizalomra és a tanulási folyamatra. Az eredmények szerint a diákok élvezték az órákat, szerettek hegedülni és szívesen játszották a múveket is, ami tükrözi a tanulók zene iránti szeretetét. A diákok örültek, hogy szüleik szeretnék, ha folytatnák zenei tanulmányaikat. A zenei órák minősége és az órákkal való elégedettség között viszont nem mutatkozott egyértelmú a kapcsolat. Motiváció szempontjából elkülönült a gyakorlás iránti attitúd és a hangszeres fejlődés iránti vágy. Annak ellenére, hogy a gyerekek örültek annak, ha tudtak haladni és tökéletesíteni tudásukat, a gyakorlással kapcsolatos kérdésekre már alacsonyabb pontokat adtak. Az énhatékonyság-érzés skálán kapott eredmények azt mutatták, hogy a tanulók főleg a saját céljaik elérése miatt gyakoroltak, azután következett a tanárnak és a szülőknek való megfelelés vágya. Egy zenei előadás során tapasztalt siker növeli az önbizalmat, ezért nem meglepő, hogy a gyerekek nagyobb élvezettel adtak elő olyan múveket, amelyekben már biztosak, azonban alacsonyan értékelték azt a kérdést, hogy mások előtt szeretnek-e játszani. A gyerekek önbizalmának legjobb prediktora a szülői támogatás volt, amit a tanár-diák kapcsolat követett (Creech \& Hallam, 2010). 


\subsection{Depresszió}

Szorongásos zavarokhoz hasonlóan a hangulatzavarok gyakrabban fordulnak elő nők körében, mint a férfiaknál (Altemus, Sarvaiya, \& Epperson, 2014). Amellett, hogy a szorongás és a depresszió hátterében hasonlóak a rizikófaktorok (Biaggi, Conroy, Pawlby, \& Pariante, 2016; Vink, Aartsen, \& Schoevers, 2008), gyakori a két zavar együttes jelenléte (Jacobson \& Newman, 2017). Longitudinális kutatások meta-analízise alapján a különböző depresszív zavarok leginkább a szociális szorongás és a specifikus fóbia erős prediktorai (Jacobson \& Newman, 2017). Langer és munkatársai szerint (2019) a hangulatingadozás lehet az a tünet, ami közös tünetként hidat képez a depresszió és a szociális szorongás között. A tünetek intenzitását a túlzottan eredményorientált nevelési stílus is befolyásolhatja (Bleys, Soenens, Claes, Vliegen, \& Luyten, 2018). Kamaszkorban a depresszió jelentős rizikófaktora a szociális interakciók hiánya, vagy elégtelensége, ezért a szülókkel és a barátokkal való pozitív kapcsolat fenntartása csökkenti a depresszív tüneteket és a szociális szorongást (Kochel, Bagwell, Ladd, \& Rudolph, 2017); míg a családi támogatás hiánya - fóleg lányoknál - később depresszióhoz és a társas interakciók elhanyagolásához vezet (Alto, Handley, Rogosch, Cicchetti, \& Toth, 2018). A depresszióhoz gyakran társul alvászavar (Li, Wu, Gan, Qu, \& Lu, 2016; Vaag, Saksvik-Lehouillier, Bjørngaard, 2015), tünetei akár a perfekcionizmus kialakulásához is vezethetnek (Vaillancourt \& Haltigan, 2018). A perfekcionizmus öt dimenziója közül leginkább a hibák miatti aggodalom és a viselkedés miatti kételyek mutatnak erős korrelációt a depresszióval (Frost, Heimberg, Holt, Mattia, \& Neubauer, 1993; Frost, Marten, Lahart, \& Rosenblate, 1990; Minarik \& Ahrens, 1996).

A múvészeti képzésben részt vevő diákoknál intenzív depresszív tüneteket figyeltek meg Young és munkatársai (2012). Kaleńska-Rodzaj (2018) a színpadra lépés előtti érzelmeket vizsgálta lengyel zenészek körében. A kutatásból kiderült, hogy egy hangverseny előtt a zenészek pozitív és negatív érzelmeket egyaránt tapasztalnak. A negatív érzelmek közül leggyakoribb a szomorúság (93\%), majd ezt követi a depresszió és a lehangoltság (80\% felett). Az előadás közben keletkező negatív érzelmi válaszok előidézhetnek depresszív tendenciát (Bannai, Kase, Endo, \& Oishi, 2016). A kedvezőtlen pszichoszociális körülmények szintén rizikófaktorai a szorongásnak és a depressziónak (Vaag, Bjørngaard, \& Bjerkeset, 2015). A pszichoszociális körülményeiket kedvezőtlennek értékelő zenekari zenészeknél kapcsolatot találtak a hallásproblémákkal (Schink, Kreutz, Busch, Pigeot, \& Ahrens, 2014). A zenészek hallása egyébként is kifinomultabb és érzékenyebb, amire negatívan hat a munkakörnyezetben jelen lévő magas hangerő. A hallás- 
problémák sok esetben kivizsgálatlanul maradnak (Schink és mtsai, 2014), ami önmagában is distresszt okoz; emellett megtalálható a perfekcionizmusból adódó aggodalom, hogy a hallásprobléma megkülönböztetné őket a többi zenekari zenésztól (Langendörfer, Hodapp, Kreutz, \& Bongard, 2006). A túlzott gyakorlás szintén negatív hatással van a hallásra. A heti 20 óránál többet gyakorló zenészeknél gyakrabban jelentkeztek hallásproblémák és egyéb mozgásszervi panaszok (Hagberg, Thiringer, \& Brandström, 2005). Könnyúzenészeknél az ízületi fájdalmakon kívül a depresszió és a szorongás volt a leggyakoribb panasz, 37\%-uk pedig halláskárosodásról számolt be (Raeburn, Hipple, Delaney, \& Chesky, 2003). Fishbein és munkatársainak (1988) vizsgálatában a depresszió és a lámpaláz gyakorisága $17 \%$ és $24 \%$ volt; leggyakoribb panasz volt a derék-, hát- és vállfájás, amelyekből legalább egyet a hangversenyekkel hoztak kapcsolatba a zenészek.

\subsection{Perfekcionizmus}

A zenei teljesítményszorongáshoz gyakran társul a tökéletességre való törekvés. Nemzetközi vizsgálatok eredményei kimutatták, hogy a perfekcionizmus gyakori jellemzóje a szorongó egyéneknek, amit egyes kutatók genetikai faktorokkal (Moser, Slane, Burt, \& Klump, 2011), míg mások helytelen coping stratégiákkal indokolnak (Dunkley, Zuroff, \& Blankstein, 2003). A perfekcionistákra jellemző alacsony önértékelés miatt a hétköznapok stresszorai erős negatív érzelmi választ váltanak ki (Klibert, Lamis, Naufel, Yancey, \& Lohr, 2015; Smith, Saklofske, Yan, \& Sherry, 2017; Smith, Sherry, és mtsai 2017). Az önmagától és másoktól elvárt maximális teljesítmény mögött gyakori az internalizált szégyen (Schalkwijk, Van Someren, \& Wassing, 2019). Kialakulása jellemzően gyermekkorban kezdődik, gyakori háttértényező a szülők felől érkező feltételhez kötött elfogadás, ezért gyermekkortól kezdve fontos, hogy megfeleljenek a szülői elvárásoknak (Frost és mtsai, 1990; Flett, Hewitt, Oliver, \& Macdonald, 2002).

A perfekcionizmus számtalan mentális zavar rizikótényezője (OddoSommerfeld, Hain, Louwen, \& Schermelleh-Engel, 2015).Vizsgálatokban kiemelkedő a perfekcionizmus és az alvászavar, szorongás, depresszió, evészavar és a személyiségzavarok közötti szoros kapcsolat (Akram, Ellis, Myachykov, Chapman, \& Barclay, 2017; Flett, Hewitt, Blankstein, \& Gray, 1998; Hewitt és mtsai, 2003; Smith, Sherry, és mtsai, 2017; Stoeber, Madigan, Damian, Esposito, \& Lombardo, 2016; Varga \& Babusa, 2012). Ez arra utalhat, hogy a perfekcionizmus fontos szerepet tölt be egyes zavarok kialakulásának hátterében és hosszú távú fennmaradásában. Ezt a jelenséget Shafran és munkatársai (2002) „klinikai” perfecionizmusként említik, ahol a személy önértékelése az önmagával támasztott magas elvárásoktól és 
a megvalósított céloktól függ. A perfekcionizmus önmagában nem tekinthetó mentális zavarnak, azonban a DSM-5 kézikönyvben a „rigid perfekcionizmus (hiánya)" definíciója megtalálható a gátlástalanság, mint személyiségdimenzió vonásai között (APA, 2013, 780. o.).

A perfekcionizmusnak több elmélete is ismert. Az utóbbi étvizedek eredményei a perfekcionizmust két típusba sorolják: adaptív és maladaptív (Hamachek, 1978; Dunkley, Blankstein, Zuroff, Lecce, \& Hui, 2006; TerryShort, Owens, Slade, \& Dewey, 1995). Az adaptív típusba tartozó személyek reális célokat túznek ki és kevésbé jellemző rájuk a mindent átszövő precizitás. Modellkövetés útján is kialakulhat, ami pozitív (identifikáció egy érzelmileg fontos személlyel) és negatív (egy érzelmileg fontos személy viselkedésének elutasítása) módon is megtörténhet. A maladaptív perfekcionizmus ezzel szemben egy neurotikus vonás, ahol alapkövetelmény a tökéletes teljesítmény, az elért eredmény azonban sosem kielégítő (Hamachek, 1978). A maladaptív perfekcionizmus szorongásos tünetei miatt csökken az önértékelés és az élettel való elégedettség, megjelenhetnek depresszióra és szociális szorongásra utaló tünetek (Chen és mtsai, 2016; Jensen, Ivarsson, Fallby, Dankers, \& Elbe, 2018; Smith és mtsai, 2018). A perfekcionizmus multidimenzionális megközelítése Frost és munkatársainak (1990) nevéhez kötődik. A konstruktum a perfekcionizmus hat különböző dimenzióját méri: hibák miatti aggodalom, önmagunktól való elvárások, szülői elvárások, szülői kritika, viselkedés miatti kételyek, és az összeszedettség. Az önmagunkkal kapcsolatos elvárások dimenzió egyéb pszichiátriai kórképek (depresszió, szorongásos zavarok, anorexia nervosa, bulimia nervosa) tüneteivel mutat összefüggést (Limburg, Watson, Hagger, \& Egan, 2016). A hibák miatti aggodalom és a viselkedés miatti kételyek - különösen nők körében - magasabb gyakoriságú szorongást eredményeznek (Minarik \& Ahrens, 1996), valamint növelik az alvászavar kockázatát (Schmidt, Courvoisier, Cullati, Kraehenmann, \& Linden, 2018). Az elmúlt három évtized kutatási eredményei alapján növekvő tendencia figyelhető meg a perfekcionizmus skálákon elért értékeknél; a fiatalok egyre többet várnak el maguktól és másoktól, továbbá úgy érzik, hogy mások elvárásai velük szemben szintén magasak (Curran \& Hill, 2019). Egy longitudinális kutatás eredményei szerint az önmagukkal szembeni kritika 8 és 11 év között csak kismértékben csökken, az internalizált tünetek pedig akkor is megmaradnak, ha a gyerekek már kevésbé kritikusak magukkal szemben (Hong és mtsai, 2016). Serdülők körében különösen a 15-18 évesek hajlamosak a túlzott elvárásokra magukkal szemben, aggódnak a hibáik miatt (Fehér \& Kasik, 2018).

Zenészek körében végzett vizsgálatokban a perfekcionizmus összefüggést mutat a zenei teljesítményszorongással, mértéke pedig nő a zenei pályán eltöltött évek során (Mor, Day, Gordon, \& Hewitt, 1995; Patston \& 
Osborne, 2016). A perfekcionizmus kognitív összetevőinek van pozitív és negatív következménye is, a hibáktól való aggodalom azonban növeli a teljesítményszorongást (Kobori, Yoshie, Kudo, \& Ohtsuki, 2011).

\section{A zenei teljesítményszorongáshoz gyakran társuló személyiségvonások}

\section{1. Énhatékonyság-érzés}

Az énhatékonyság-érzés, ami az egyénnek abba vetett hitét jelenti, hogy képes megoldani az előtte álló feladatokat, az énszabályozás által szintén kihat a teljesítményre és a teljesítményszorongásra (Lee, Lee, \& Bong, 2014). Az önmagunkról kialakult szubjektív hiedelmeinknek döntő szerepe van a személyiség pozitív irányban történő fejlődésében (Bong \& Skaalvik, 2003). Az önbecsülés és a pozitív énkép által nő a kompetenciaérzés, mivel erősödik a képességekbe vetett hit (Wigfield \& Eccles, 1994). Az énhatékonyság-érzés fontos a lámpalázzal való megküzdésben, mivel magas értéke negatívan korrelál a tehetetlenséggel és a pesszimizmussal (Orejudo, ZarzaAlzugaray, Casanova, Rodríguez-Ledo, \& Mazas, 2016), a teljesítményszorongással (Qudsyi \& Putri, 2016), ezen kívül pozitív érzéseket generál önmagunkról és a környezetünkről (Bajaj, Robins, \& Pande, 2016). Alacsony volta tükrözheti a társas támogatás hiányát és a negatív életeseményeket (Raknes és mtsai, 2017).

Ritchie és Williamon (2010) a zenei énhatékonyság-érzés típusait vizsgálták középiskolás és egyetemista zenészek között. A kutatásból kiderült, hogy a tanuláshoz szükséges énhatékonyság-érzés szintje középiskolás zenészek között magasabb, mint az egyetemista zenészek körében, azonban az előadói énhatékonyság-érzés szintjében nincs szignifikáns különbség a két csoport között. A szakmai énhatékonyság-érzés növelése történhet kognitív, viselkedéses és affektív szinten egyaránt, ami hatékonyabbá teszi a hangszeren való gyakorlást (McPherson, Osborne, Evans, \& Miksza, 2019) és növeli az iskolai teljesítményt (Talsma, Schüz, Schwarzer, \& Norris, 2018). Ericsson (1997) szerint a zenész tanulóknál gyakori stratégia egy olyan szociális támogatórendszer kialakítása, ahol előtérbe kerül a tanárokkal és a társakkal való pozitív kapcsolatrendszer fenntartása. Az egyetem kezdő éveiben a szociális környezet nagyban formálja az énhatékonyságérzést, ami pedig kihat a tanulási folyamat gyorsaságára is, különösen lányok körében (Nielsen, 2004). Egy három napig tartó megfigyelés során Hendricks (2014) szintén megerősítette a zenei környezet és a növekvő énhatékonyság közötti kapcsolatot, habár a versenyszerú légkör hatására lányoknál kissé lassabb volt ez a folyamat. McPherson és McCormick (2006) 
9-18 éves hangszeres előadókat vizsgálva erős összefüggést találtak az énhatékonyság-érzés és a zenei előadás minősége között. Egy zenei vizsgára való felkészülés napi több óra gyakorlást igényel egy fél éven keresztül, a napról napra való haladási szint azonban nagyon lassú. A precíz munkához, a hibák javításához és a zenei múvek egyes részeinek órákon át való gyakorlásához sok türelem, kitartás és magas énhatékonyság-érzés szükséges. A pedagógus növelheti a diák énhatékonyság-érzését azzal, ha támpontokat ad az előadási múvek sorrendjét illetően. McPherson és McCormick (2006) szerint pozitívan hat az előadás minőségére, ha az eljátszandó múvek nem feltétlenül a zenei korszakok szerinti sorrendet követik, hanem a diák olyan darabbal tud kezdeni, amelynek előadásában biztosabb.

\subsection{Egyéb társuló vonások: vonásszorongás, neuroticizmus, negatív affektivitás, extraverzió és intraverzió}

A vonásszorongás a személyiség fontos dimenzióját képezi a legtöbb személyiségelméletben (Eysenck, 1997). Jellemezhető az egyén általános hajlamaként, hogy aggodalommal és szorongásal reagáljon különböző helyzetekben, amely fóleg az önbizalmat fenyegető szociális helyzetekben nyilvánul meg (Spielberger, Gonzalez-Reigosa, Martinez-Arratia, Natalicio, \& Natalicio, 1971). Zenészeknél a vonásszorongás szignifikánsan magasabb a populáció átlagához képest (Kenny, 2004), a nemmel együtt pedig ez a két változó erős prediktora a zenei teljesítményszorongásnak (Osborne, Kenny, \& Holsomback, 2005; Ryan, 2005). Kaspersen és Gotestam (2002) norvég zenészek előadással kapcsolatos pozitív és negatív érzelmeinek vizsgálatában azt találták, hogy az előadás előtt és az előadás közben jelentkező szorongás a negatív affektivitással volt összefüggésben.

Számos vizsgálat eredménye szerint a stresszel való sikeres megküzdés egyes személyiségvonások meglététől függ, vagyis különböző vonások a coping eltérő formáival járnak együtt. Az optimizmus rendszerint olyan a stratégiákkal társul, amelyek a stresszt kiváltó esemény megszüntetésére irányulnak (Nes \& Segerstrom, 2006; Scheier \& Carver, 1985). Az extraverzó dimenzió pedig a probléma- és érzelemorientált megküzdés használatában nyilvánul meg (Kardum \& Krapić, 2001). Ezzel ellentétben a személyre jellemző neuroticizmus és pszichoticizmus leginkább az elkerülő coping mechanizmus használatát vonja maga után (Kardum \& Krapić, 2001; Kaiseler, Levy, Nicholls, \& Madigan, 2017). A neuroticizmus, mint családon belül örökölhető vonás a depresszió erős rizikófaktora (Lake, Eaves, Maes, Heath, \& Martin, 2000), így hatással van az általános jóllétre (Creed \& Evans, 2002). Smith és Rickard (2004) ausztrál serdülők mintáján vizsgálták a lámpaláz 
hátterében lévő személyiségvonásokat. A zenei teljesítményszorongást magyarázó modell közel 70\%-át magyarázták a nem, a neuroticizmus, a vonásszorongás és az extraverzió.

Sinden (1999) a zenei teljesítményszorongást, énhatékonyság-érzést, perfekcionizmust és a coping stratégiákat vizsgálta egyetemi képzésben résztvevő zenészek körében. Az alacsony énhatékonyság-érzés és önbizalom, a perfekcionizmus három dimenzója és az érzelemfókuszú megküzdés szignifikáns prediktorai voltak a zenei teljesítményszorongásnak. Az erősen és a kevésbé szorongó egyének közötti különbség abban nyilvánult meg, hogy milyen gyakran használták az emóciófókuszú és az elkerülő megküzdési mechanizmust, valamint aggódtak-e a hibáik miatt. Míg férfiakra jellemzóbb volt az elkerülő coping stratégia, addig a nők magasabb teljesítményszorongásról számoltak be, és több szülői elvárást, illetve kritikát tapasztaltak (Sinden, 1999).

\section{A zenei teljesítményszorongás kezelési lehetőségei}

Rendkívül fontos a szorongás kezdeti tüneteinek korai felismerése és mihamarabbi kezelése, mivel ezzel megelőzhető vagy csökkenthető a később már súlyos formában jelentkező tünetek hatása (Hughes, Mohatt, Bennett, \& Walkup, 2015). A zenei teljesítményszorongás kezeléséről szóló kutatások eredményei alapján két csoport különíthető el: gyógyszeres és nem gyógyszeres terápia. A gyógyszeres kezelés gyakran történik szelektív szerotonin visszavétel gátlók (SSRI - pl. paroxetin) és benzodiazepinek segítségével (Blanco, Bragdon, Schneier, \& Liebowitz, 2013). A nem gyógyszeres kezelés esetében hatékony eljárásnak bizonyult a hipnoterápia, viselkedésterápia, kognitív terápia, és a kognitív viselkedésterápia. A terápiával párhuzamosan vagy önállóan, megelőzésképp is alkalmazható a sport, meditáció és a jóga.

A fellépések előtti gyors szívverés, remegés és szájszárazság farmakológiai kezelésen belül csökkenthető béta-blokkolókkal (blokkolják az adrenalin hatását a béta-receptorokra), antidepresszív (SSRI) és szorongásoldó szerekkel (benzodiazepinek). Több tanulmány is vizsgálta már a béta-blokkolók hatását (Berens \& Ostrosky, 1988; Brandfonbrener, 1990; Lederman, 1999; Nubé, 1991), mivel ez a leggyakrabban használt szorongás elleni gyógyszer a zenészek között (Dalrymple, 2005; Fishbein és mtsai, 1988; Kenny és mtsai, 2012; Rosenthal, 2000). A benzodiazepinek hatékonyan enyhítik a szorongást, azonban mellékhatásaik miatt hosszútávú alkalmazásuk nem ajánlott (Ashton, 2002; Birk, 2004). James és Savage (1984) a bétablokkoló (nadolol) és a benzodiazepine (diazepam) zenei teljesítményszorongásra való hatását vizsgálták zenészek körében. A béta-blokkoló ál- 
tal a szívritmus és a kézremegés csökkent, ami megkönnyítette a zenei előadást. Vizsgálatukban egyik gyógyszer sem csökkentette a szorongást, sőt, a diazepam hatására romlott a zenei teljesítmény (James \& Savage, 1984).

A hangversenyek során mért pulzusszám nagyon magas lehet, ezért a szívritmus lassítása fontos szempont a tünetek kezelése során. Iñesta, Terrados, García és Pérez (2008) vizsgálatának eredményei szerint a zenészek szívverése koncert közben szignifikánsan magasabb a gyakorlás közben mért értékhez képest. Emellett különbségeket figyeltek meg különböző hangszeres csoportok (fúvósok, vonósok, és zongoristák) szívverése között. Hangverseny közben a zongoristáknál volt a legmagasabb a szívverések száma: percenként megközelítette a 167-et. Ez nagy megterhelést jelent a gyakorlás közben, nyugodt állapotban mért 116-os értékhez képest (Iñesta és mtsai, 2008). A béta-blokkoló gyógyszerek segítségével csökken a szívdobogás, a vérnyomás és a gyakori vizelési inger, megszúnik vagy csökken a kézremegés (Patston \& Loughlan, 2014). Mivel ezek nem kifejezetten szorongáscsökkentő gyógyszerek, a személy lámpaláza nem csökken, de a szorongás jellegzetes tüneteinek "tompítása” az adott helyzetben egy viszonylag nyugodt állapot látszatát hozhatja létre. Megszabadulva a tünetek okozta testi érzésektől, az előadó megkönnyebbülést tapasztal, figyelme az előadásra helyeződik át és jobban tud koncentrálni a zenére. Alacsony teljesítményszorongás esetében a béta-blokkolók alkalmazása hatékony kezelési módszer lehet (Patston \& Loughlan, 2014).

Aggodalomra ad okot az a tény, hogy a megkérdezettek gyakran orvosi konzultáció nélkül jutnak hozzá a gyógyszerhez, amelynek a nem megfelelő adagolás következtében csökken a jótékony hatása (Fishbein és mtsai, 1988; Kenny és mtsai, 2012). A béta-blokkoló gyógyszerek hatása természetesen függ az egyén szervezetének állapotától. Annak ellenére, hogy az alkalmankénti teljesítményszorongás csillapításához bevett mennyiség minimális veszéllyel jár, az ennél gyakoribb használat magasabb dózisban már hemodinamikus változásokat idéz elő (Brandfonbrener, 1990). A béta-blokkolók célja csökkenteni a szívverést, ha azonban túl magas a dózis vagy egyéb szív-és érrendszeri betegség is jelen van, a gyógyszer túlzott hatást fejthet ki a szívre, ami akár szívleálláshoz is vezethet (Patston \& Loughlan, 2014).

A lámpaláz egyik kezelési módszere lehet a kognitív viselkedésterápia (Cognitive Behavioral Therapy; CBT), amelynek célja azonosítani azokat a helyzeteket, ahol megjelennek a szorongást keltő diszfunkcionális gondolatok. A kognitív terápia már gyermekkortól kezdve alkalmazható szorongásos zavarok esetén (Cartwright-Hatton, Roberts, Chitsabesan, Fothergill, \& Harrington, 2004; Wang és mtsai, 2017), ami akár online módon is végezhető (Carlbring, Andersson, Cuijpers, Riper, \& Hedman-Lagerlöf, 2017). 
A terápia hatására nő az önbizalom; a személy megtanulja reálisan értékelni a helyzetet, mivel megváltoznak az önmagáról alkotott téves hiedelmei (Gregory \& Peters, 2017; Rodebaugh \& Chambless, 2004). Egyik változatát - a virtuális valóság terápiát - a szorongásos zavarok sikeres kezelése után már zenészek körében is alkalmazták (Bissonnette, Dubé, Provencher, \& Moreno Sala, 2016; Williamon, Aufegger, \& Eiholzer, 2014). A kezelés egy program segítségével valósul meg, amelyben a virtuális közönség különböző viselkedéses válaszokkal reagál az előadói tevékenységre (mosoly, taps). A közönség pozitív visszajelzését látva az előadó szorongása csökken, az előadáshoz pedig pozitív élmény társul. A kognitív terápiák harmadik hulláma a tudatos jelenlétet és az elfogadást helyezi a központba. Az elfogadás és elköteleződés terápia (Acceptance and Commitment Therapy; ACT) során a személy megtanulja változtatás nélkül elfogadni a negatív érzéseket és gondolatokat. Az elfogadás által nő az élettel való elégedettség, valamint csökken a szorongás (Juncos \& de Paiva e Pona, 2018; Grégoire, Lachance, Bouffard, \& Dionne, 2018; Hayes, 2004; Viskovich \& Pakenham, 2018). Juncos és Markman (2016) elsőként vizsgálták az ACT terápiát zenészek körében. A terápiát követóen a zenei teljesítményszorongás és az emiatt érzett szégyenérzet jelentős mértékben csökkent (Juncos és mtsai, 2017; Juncos \& Markman, 2016).

A szervezet optimális múködését elósegító és az érzelmi distresszt csökkentő új készségek kialakítása által csökkenhet a zenei teljesítményszorongás mértéke. Kifejezetten erre a célra alkalmazható a tudatos jelenlét (mindfulness), mivel a meditáció során tapasztalt érzelmek és gondolatok tudatosítása pozitív változást hoz létre (Smalley \& Winston, 2010). A tudatosságalapú meditáció során megfigyeljük a körülöttünk zajló folyamatokat és az adott pillanatban tapasztalt belső érzéseket (pl. szívverés, légzés, testhelyzet, izmok állapota). Kutatások eredményei szerint a rendszeres meditáció hozzájárul a szorongásos zavarok (Goldin \& Gross, 2010; Miller, Fletcher, \& Kabat-Zinn, 1995; Spijkerman, Pots, \& Bohlmeijer, 2016) és a depresszió tüneteinek enyhüléséhez (Newby, McKinnon, Kuyken, Gilbody, \& Dalgleish, 2015; Shapero és mtsai, 2018; Winnebeck, Fissler, Gärtner, Chadwick, \& Barnhofer, 2017). Generalizált szorongás esetében javul a stresszel való megküzdés (Hoge és mtsai, 2018). A zenészek körében végzett vizsgálatok eredményei szerint a tudatos cselekvés megküzdési mechanizmusként múködik a zenei teljesítményszorongás ellen (FarnsworthGrodd, 2012); a vonásszintú tudatos jelenlét pedig akadályozza a romboló önkritika megjelenését, ezáltal csökken a teljesítményszorongás negatív hatása a múvészi pályára (Rodríguez-Carvajal, Lecuona, Vilte, MorenoJiménez, \& de Rivas, 2017). Khalsa és Cope (2006) vizsgálatában a zenészek egy két hónapig tartó jóga és meditációs táborban vettek részt. A program végén a gyakoribb volt a flow élmény, a zenei teljesítményszorongás szintje 
pedig alacsonyabb volt a kezdeti értékhez képest (Khalsa \& Cope, 2006). Más tanulmányok eredményei is azt mutatják, hogy jóga hatására a lámpaláz csökken (kontrollcsoporthoz képest), ami korrelál a megnövekedett flow és tudatosság érzésével (Butzer, Ahmed, \& Khalsa, 2015; Khalsa, Butzer, Shorter, Reinhardt, \& Cope, 2013).

A zenei teljesítményszorongás jelenlétének felismerése ellenére a felsőoktatási intézményekben kevés az olyan kurzus, ahol a diákok megismerkedhetnek az előadást segító gyakorlatokkal. A tanulókban megvan az igény, hogy segítségért forduljanak, azonban nem tudnak megfelelő tájékoztatást kapni, mivel az oktatók nem beszélnek őszintén a problémáról (Patston \& Loughlan, 2014). A kutatási eredmények azt mutatják, hogy az előadói tevékenység fejlesztését megcélzó szakmai programok hatása több területen is megnyilvánul. Egy kilenchetes program során a zenei konzervatóriumban tanuló diákok egy zenei képességfejlesztő programban vettek részt (Clark \& Williamon, 2011). A program végére a tanulók gyakorlásról alkotott elképzelései pozitív irányba változtak, az előadással összefüggó énhatékonyságérzés pedig szignifikánsan nőtt. A résztvevők a képzés befejezését követően nagyobb önbizalmat éreztek, javult az öntudatuk és a szorongás feletti kontrollérzetük; ezen kívül a zenéléshez egy pozitív, egészséges hozzáállás jött létre (Clark \& Williamon, 2011). További eredmények is azt mutatják, hogy a szorongáscsökkentő gyakorlatokat tartalmazó előadássorozatok jó hatással vannak a zenei képességekre. Egy másik, szintén konzervatóriumi zenészeknek tartott mesterkurzussorán 11, zenei előadással kapcsolatos stratégiával ismerkedhettek meg a diákok (Osborne, Greene, \& Immel, 2014). A részvétel során elsajátított technikáknak köszönhetóen szignifikánsan javult a memorizálás képessége, a koncentráció, az előadással járó stresszre vonatkozó túrőképesség és a hibák utáni nyugalom visszaszerzése, valamint nőtt az önbizalom (Osborne és mtsai, 2014).

\section{Következtetés}

Az összefoglaló alapján elmondható, hogy a zenei teljesítményszorongás minden korosztályban előforduló jelenség. Nemi különbségeket tekintve nőknél gyakrabban megfigyelhető (Fishbein és mtsai, 1988; Iuscaa, \& Dafinoiu, 2012; LeBlanc, Jin, Obert, \& Siivola, 1997). A vizsgálatok eredményei arra utalnak, hogy idősebb zenészeknél alacsonyabb a lámpaláz mértéke (Steptoe \& Fidler, 1987), így feltételezhető, hogy az életkor előrehaladtával a teljesítményszorongás csökken. Az életkor és a lámpaláz közötti negatív összefüggés azzal is magyarázható, hogy az erősen szorongó idősebb zenészek előbb-utóbb felhagynak a hangversenyezéssel (Steptoe \& Fidler, 1987). Ezen kívül a gyakori fellépések miatti rutin hozzájárulhat ah- 
hoz, hogy a képzett zenészeknél ritkább a lámpaláz (Biasutti, \& Concina, 2014), habár intenzitás tekintetében megegyezik a szakmailag alacsonyabb képzettséggel rendelkező zenészek szorongásának mértékével (Ryan \& Andrews, 2009). Gorges és munkatársai (2007) az életkor helyett a szakmai tapasztalatot és a gyakori fellépéseket emelik ki, mint szorongást csökkentő tényezőket. A hangszer típusának szintén hatása van a zenei teljesítményszorongás mértékére. Más hangszerekkel összehasonlítva az énekesek, vonósok és billentyúsök szorongása szignifikánsan magasabb (Iuscaa, \& Dafinoiu, 2012; Vaag és mtsai, 2015). A zenei stílusokat összehasonlító vizsgálatok leginkább a klasszikus zenészeket emelik ki, mint leginkább szorongókat, ami főleg szóló előadások során nyilvánul meg (Nicholson és mtsai, 2014; Papageorgi és mtsai, 2011; Topoğlu és mtsai, 2018; LeBlanc és mtsai, 1997). A zenei teljesítményszorongás kialakulását magyarázó fóbb modellek hangsúlyozzák azt a kondicionálási folyamatot, amely során az előadás közben tapasztalt vegetatív tünetek és negatív érzelmek összekapcsolódnak az előadással (Kenny, 2010). Mivel a krónikus teljesítményszorongás rendkívül megnehezíti az előadói pályát, ezért nő a burnout kockázata, az erős szorongás akár pályaelhagyáshoz is vezethet. A vizsgálatok eredményei arra is rámutattak, hogy a zenészek többsége szeretne többet megtudni a lámpalázról és a kezelési lehetőségeiről, azonban kevesen fordulnak szakemberhez (Fehm, \& Schmidt, 2006).

A zenei teljesítményszorongást az utóbbi évtizedben specifikus fóbiaként említi a szakirodalom (Barbar és mtsai, 2014; Kenny, 2006; Nicholson és mtsai, 2014). Specifikus fóbia esetében a személy csak egy bizonyos helyzetben (a jelen kontextusban a zenei előadás során) érez szorongást, más szociális helyzetek nem váltanak ki szorongást. A lámpaláz és a szociális szorongás együttes mérésekor erős a két változó közötti kapcsolat (Barbar és mtsai, 2014; Gorges, Alpers, \& Pauli, 2007; Osborne, \& Kenny, 2005), a szociális szorongás skálákon elért értékek viszont szintén elég magasak (Andrade és mtsai, 2012; Dobos, Piko, \& Kenny, 2018). Feltételezhető, hogy a zenei teljesítményszorongáshoz kapcsolódó tünetek (elpirulás, remegés, izzadás) nemcsak egy specifikus helyzetben (pl.: egy hangverseny során), egyéb szociális helyzetekben is megnyilvánulnak. A zenészek nagy része igyekszik elkerülni a kritikát, a nyilvánosság előtti beszédet, valamint félelemmel tölti el óket a mások elótti megszégyenülés gondolata (Dobos \& Pikó, 2017). Jelentős különbségként említhetó meg az, hogy míg a szociális fóbiára jellemző a menekvés egy olyan helyzetből, ami feltételezhetóen szenvedést fog okozni, illetve az ilyen helyzetek tudatos elkerülése, a lámpaláz csak erós esetben vált ki hasonló reakciót. A zenei teljesítményszorongás akár intenzív volta ellenére a zenészek igyekeznek erejüket összeszedve túljutni az előadáson vagy versenyhelyzeten (Kenny, 2010). Ennek hátterében lehet az, hogy a fellépéssel járó szégyent valamelyest ellensúlyozza 
a perfekcionizmus, de a pedagógusok és/vagy a szülők által elvárt hibátlan teljesítmény szintén egyfajta motivációként szolgálhat. A szorongó személy a tökéletességre való törekvés által próbál megfelelni másoknak, jobb színben feltüntetni magát, ezáltal kompenzálja az alacsony önbizalomból eredő hiányosságait.

Korábban kapcsolatot találtak a szülők és gyermekeik szociális fóbiája között (Lieb és mtsai, 2000). A szorongó szülők viselkedésüket és gondolkodásmódjukat kivetítik gyermekeikre, akik később ezt a mintát követik a szociális helyzetek kiértékelésekor. A szülői minta súlyosbíthatja a meglévő vonásszorongást és a perfekcionizmus kialakulásában is szerepet képezhet. A szülők szemében való tökéletlenség érzése szégyennel, búntudattal és negatív érzésekkel társul. Amellett, hogy a szégyen és az alacsony önértékelés a perfekcionizmus fennmaradásának egyik tényezője, a szégyenre való hajlam többek között összefüggésbe hozható olyan mentális zavarokkal, mint a specifikus fóbia, generalizált szorongás, depresszív zavar és evészavar (Vizin \& Unoka, 2015). A szociális szorongás és a depresszió hat a társas kapcsolatok minőségére. A környezettől való menekvés következményeként sérülhetnek a baráti kapcsolatok, amelyek egyébként hozzájárulnának az énhatékonyság-érzésnöveléséhez (Ericsson, 1997; Nielsen, 2004).

A lámpaláz kezelését illetően már sok olyan módszer alkalmazható, ami a zenei teljesítményszorongást célozza meg. Kimutatható szociális szorongás esetén további vizsgálat tárgyát képezheti a komorbid depresszió, mivel a két zavar növeli egymás intenzitását és további zavarokhoz és maladaptív viselkedési mintákhoz vezethet (Jacobson \& Newman, 2017). Erős lámpaláz esetén a pánikzavar és a generalizált szorongás zavar szintén felmerülhet, mint komorbid zavar (Barbar és mtsai, 2014). A társuló zavarok miatt a kezelés igencsak komplex.

Amellett, hogy fontos a megfelelő terápia kiválasztása, a szociális fóbia és a perfekcionizmus leküzdéséhez elengedhetetlen az alacsony önértékelés és önbizalom helyreállítása. A szociális helyzetekben megjelenő negatív gondolatok és a rumináció kritikus átgondolása szükséges. Hangverseny előtt a negatív érzések elnyomása helyett inkább azok tudatosítása jelenthet előrelépést. A legtöbb szorongást a hibáktól való aggodalom okozza, mivel ezáltal az előadó úgy érzi, hogy megszégyenül mások előtt (pl. tanár, szülők, barátok). A szégyenérzetet először a szülőkkel való kapcsolat során tapasztaljuk. Gyermekkorban a szülők által negatívnak minősített cselekvés, gondolat, vagy érzés az adott helyzetben mélyen elraktározódik. Később egy hasonló helyzetben a szülők szavai (pl.: Nem szégyelled magad?) újból előtörhetnek. Egy zenei előadás értékelése szubjektív módon történik, ezért szinte lehetetlen elvárás, hogy mindenkinek megfeleljen. A pozitív visszajelzések ellenére a közönségben mindig lesznek olyan emberek - akár maguk a szülők-, akik a féléves munka eredményéből, az egyéni fejlődést 
figyelmen kívül hagyva csak a hibákat emelik ki. Megoldásképpen önmagunk értékelését el kell különíteni attól, hogy más emberek mit gondolnak rólunk. Ha kevésbé vagyunk kiszolgáltatva mások véleményének, elfogadjuk és megértjük, hogy miért keletkeznek a negatív érzések és gondolatok, akkor a szégyen csökkenni fog.

Ahhoz, hogy a pedagógus megtehesse a kezdő lépéseket a probléma megoldása felé, órai munka során érdeklődhet a növendék általános közérzetéről, társakkal és szülőkkel való interakciók minőségéről. Aggodalom esetén ez egy visszajelzési lehetőséget jelent a szülők felé.Tanítási környezetben nagy hangsúlyt kell fektetni a dicséret minden formájára. A dicséretnek lányok esetében különösen jótékony a hatása, hiszen ők hajlamosabbak a szorongásra (Maldonado és mtsai, 2013). Pozitív visszajelzésekkel növeljük a diák önbizalmát, és olyan környezetet teremtünk, ahol az adott tanuló feltétel nélküli elfogadást tapasztal. Utóbbi különösen fontos, hiszen a feltételhez kötött elfogadás erős rizikófaktora a perfekcionizmus kialakulásának (Flett, Hewitt, Oliver, \& Macdonald, 2002; Frost és mtsai, 1990). Kerülendő a tanulók egymás közötti összehasonlítása, ami kiválthatja a versengést és növelheti a perfekcionizmust. Ha a növendék szorongásra és perfekcionizmusra hajlamos, először emeljük ki a pozitívumokat és fektessünk minél kevesebb hangsúlyt a hibákra. Zenei órán a perfekcionizmus legegyszerúbb megnyilvánulása a hibátlan előadásra való törekvés. Ennek gyakran hangot is adnak, büszkén mondják tanáruknak, hogy egyszer sem hibáztak. Jellemző, hogy ellenkező esetben, még mielőtt a tanár bármit is közbeszólna, már jön is a felsorolás, hogy mit és hogy rontottak el. Ezután visszatérnek az előző helyre a kottában és addig gyakorolják az adott ütemet, amíg el nem tudják játszani hiba nélkül. Más gyerekekkel ellentétben a gyakorlás nem jelent problémát, sőt, aggódnak, hogy nincsenek-e lemaradva, sok esetben szeretnek előre dolgozni és túlteljesítik a követelményt.

A szociális szorongást fokozza a napi több óra egyedüllét, amit a zenészek gyakorlással töltenek. Az introverzió gyakran jellemzi a zenészeket, amely akár adaptív vonás is lehet, azonban gyakran társul vonásszorongással (Woody \& McPherson, 2010). Hasznos lehet ilyen esetekben a másokkal történő együtt zenélés, közös zenei program, mivel ez egyrészt jó hatással van a társas kapcsolatokra, másrészt a szóló elóadással ellentétben kevesebb szorongással jár a múvek előadása. A mások előtti megszégyenülés félelme miatt fokozottan ügyeljünk arra, hogy a növendéket minden esetben négyszemközt értékeljük, mivel sok tanuló szorong, ha mások előtt kerül ilyen helyzetbe (pl. osztálytársak, barátok, szülők). Tudassuk a tanulóval, hogy nem elvárás a tökéletes teljesítmény. Igyekezzünk az igazságos és együttérző hozzáállásra, az értékelést végezzük jóindulattal, ahol figyelembe vesszük a tanuló önmagához viszonyított fejlődését. A belső, intrinzik 
motiváció akkor nő, amikor a tanuló úgy érzi, hogy veszély nélküli, támogató és gondoskodó zenei környezet veszi körül (Woody \& McPherson, 2010).

\section{Irodalom}

Akram, U., Ellis, J.G., Myachykov, A., Chapman, A.J., \& Barclay, N.L. (2017). Anxiety mediates the relationship between multidimensional perfectionism and insomnia disorder. Personality and Individual Differences, 104, 82-86.

Altemus, M., Sarvaiya, N., \& Epperson, C.N. (2014). Sex differences in anxiety and depression clinical perspectives. Frontiers in Neuroendocrinology, 35(3), 320-330.

Alto, M., Handley, E., Rogosch, F., Cicchetti, D., \& Toth, S. (2018). Maternal relationship quality and peer social acceptance as mediators between child maltreatment and adolescent depressive symptoms: Gender differences. Journal of Adolescence, 63, 19-28.

American Psychiatric Association (2013). Diagnostic and statistical manual of mental disorders ( $5^{\text {th }}$ ed.). Washington, DC: American Psychiatric Association

Andrade, L.H., Wang, Y.P., Andreoni, S., Silveira, C.M., Alexandrino-Silva, C., Sui, E.R., et al. (2012). Mental disorders in megacities: Findings from Sao Paulo megacity mental health survey, Brazil. PloS ONE, 7(2), e31879.

Ashton, H. (2002). Benzodiazepine Abuse. In W. Caan, \& J. Belleroche (Eds.), Drink, drugs and dependence (197-212). London, New York: Harwood Academic Publishers

Bajaj, B., Robins, R.W., \& Pande, N. (2016). Mediating role of self-esteem on the relationship between mindfulness, anxiety, and depression. Personality and Individual Differences, 96, 127-131.

Bandelow, B., Charimo Torrente, A., Wedekind, D., Broocks, A., Hajak, G., \& Rüther, E. (2004). Early traumatic life events, parental rearing styles, family history of mental disorders, and birth risk factors in patients with social anxiety disorder. European Archives of Psychiatry and Clinical Neuroscience, 254(6), 397-405.

Bannai, K., Kase, T., Endo, S., \& Oishi, K. (2016). Relationships among performance anxiety, agari experience, and depressive tendencies in Japanese music students. Medical Problems of Performing Artists, 31(4), 205-210.

Barbar, A.E.M., Crippa, J.A., \& Osório, F. (2014). Performance anxiety in Brazilian musicians: Prevalence and association with psychopathology indicators. Journal of Affective Disorders, 152, 381-386.

Barlow, D.H. (2000). Unravelling the mysteries of anxiety and its disorders from the perspective of emotion theory. American Psychologist, 55(11), 1247-1263.

Barlow, D.H. (2002). True alarms, false alarms, and learned (conditioned) anxiety: The origins of panic and phobia. In D.H. Barlow, Anxiety and its disorders - the nature and treatment of anxiety and panic (219-250). London: The Guilford Press

Berens, P.L. \& Ostrosky, J.D. (1988). Use of beta-blocking agents in musical performance induced anxiety. Drug Intelligence and Clinical Pharmacy, 22, 148-149.

Bernhard, C. (2010). A survey of burnout among college music majors: A replication. Music Performance Research, 3(1), 31-41.

Biaggi, A., Conroy, S., Pawlby, S., \& Pariante, C. M. (2016). Identifying the women at risk of antenatal anxiety and depression: A systematic review. Journal of Affective Disorders, 191, 62-77.

Biasutti, M., \& Concina, E. (2014). The role of coping strategy and experience in predicting music performance anxiety. Musicae Scientiae, 18(2), 189-202. 
Birk, L. (2004). Pharmacotherapy for performance anxiety disorders: Occasionally useful but typically contraindicated. Journal of Clinical Psychology, 60(8), 867-879.

Bissonnette, J., Dubé, F., Provencher, M.D., \& Moreno Sala, M.T. (2016). Evolution of music performance anxiety and quality of performance during virtual reality exposure training. Virtual Reality, 20(1), 71-81.

Blanco, C., Bragdon, L.B., Schneier, F.R., \& Liebowitz, M.R. (2013). The evidence-based pharmacotherapy of social anxiety disorder. International Journal of Neuropsychopharmacology, 16(1), 235-249.

Bleys, D., Soenens, B., Claes, S., Vliegen, N., \& Luyten, P. (2018). Parental psychological control, adolescent self-criticism, and adolescent depressive symptoms: A latent change modeling approach in Belgian adolescents. Journal of Clinical Psychology, 74(10), 18331853.

Blumenthal, H., Taylor, D.J., Cloutier, R.M., Baxley, C., \& Lasslett, H. (2019). The links between social anxiety disorder, insomnia symptoms, and alcohol use disorders: Findings from a large sample of adolescents in the United States. Behavior Therapy, 50(1), 50-59.

Bonde, L.O., Juel, K., \& Ekholm, O. (2018). Associations between music and health-related outcomes in adult non-musicians, amateur musicians and professional musicians Results from a nationwide Danish study. Nordic Journal of Music Therapy, 27(4), 262-282.

Bong, M., \& Skaalvik, E.M. (2003). Academic self-concept and self-efficacy: How different are they really? Educational Psychology Review, 15(1), 1-40.

Boucher, H., \& Ryan, C.A. (2010). Performance stress and the very young musician. Journal of Research in Music Education, 58(4), 329-345.

Brandfonbrener, A.G. (1990). Beta blockers in the treatment of performance anxiety. Medical Problems of Performing Artists, 5(1), 23-26.

Butzer, B., Ahmed, K., \& Khalsa, S.B.S. (2015). Yoga enhances positive psychological states in young adult musicians. Applied Psychophysiology and Biofeedback, 41(2), 191-202.

Canals, J., Voltas, N., Hernández-Martínez, C., Cosi, S., \& Arija, V. (2018). Prevalence of DSM-5 anxiety disorders, comorbidity, and persistence of symptoms in Spanish early adolescents. European Child \& Adolescent Psychiatry, 28(1), 131-143.

Carlbring, P., Andersson, G., Cuijpers, P., Riper, H., \& Hedman-Lagerlöf, E. (2017). Internetbased vs. face-to-face cognitive behavior therapy for psychiatric and somatic disorders: an updated systematic review and meta-analysis. Cognitive Behaviour Therapy, 47(1), $1-18$.

Cartwright-Hatton, S., Roberts, C., Chitsabesan, P., Fothergill, C., \& Harrington, R. (2004). Systematic review of the efficacy of cognitive behaviour therapies for childhood and adolescent anxiety disorders. British Journal of Clinical Psychology, 43(4), 421-436.

Chen, L., Zhong, M., Cao, X., Jin, X., Wang, Y., Ling, Y., et al. (2016). Stress and self-esteem mediate the relationships between different categories of perfectionism and life satisfaction. Applied Research in Quality of Life, 12(3), 593-605.

Clark, T., \& Williamon, A. (2011). Evaluation of a Mental Skills Training Program for Musicians. Journal of Applied Sport Psychology, 23(3), 342-359.

Coelho, V.A., \& Romão, A.M. (2018). The relation between social anxiety, social withdrawal and (cyber)bullying roles: A multilevel analysis. Computers in Human Behavior, 86, 218226.

Conway, K.P., Swendsen, J., Husky, M.M., He, J.-P., \& Merikangas, K.R. (2016). Association of lifetime mental disorders and subsequent alcohol and illicit drug use: Results from the national comorbidity survey - adolescent supplement. Journal of the American Academy of Child \& Adolescent Psychiatry, 55(4), 280-288. 
Creech, A. (2010). Learning a musical instrument: the case for parental support. Music Education Research, 12(1), 13-32.

Creech, A., \& Hallam, S. (2010). Learning a musical instrument: The influence of interpersonal interaction on outcomes for school-aged pupils. Psychology of Music, 39(1), 102-122.

Creed, P.A. , \& Evans, B.M. (2002). Personality, well-being and deprivation theory.Personality and Individual Differences, 33(7), 1045-1054 .

Crome, E., Grove, R., Baillie, A.J., Sunderland, M., Teesson, M., \& Slade, T. (2014). DSM-IV and DSM-5 social anxiety disorder in the Australian community. Australian and New Zealand Journal of Psychiatry, 49(3), 227-235.

Curran, T., \& Hill, A.P. (2019). Perfectionism is increasing over time: A meta-analysis of birth cohort differences from 1989 to 2016. Psychological Bulletin, 145(4), 410-429.

Dalrymple,G.V.(2005). Medical issues and horn playing: Beta blockers and stage fright (performance anxiety). The Horn Call - Journal ofthe International Horn Society, 35(2), 69-70.

Davidson, J.W., Moore, D.G., Sloboda, J.A., \& Howe, M.J.A. (1998). Characteristics of music teachers and the progress of young instrumentalists. Journal of Research in Music Education, 46(1), 141-160.

Dobos, B., \& Pikó, B. (2017). A zenei teljesítményszorongás összefüggése a perfekcionizmussal és a szociális fóbiával. Magyar Pedagógia,117(3), 241-256.

Dobos, B., Piko, B., Kenny, \& Kenny, D.T. (2018). Music performance anxiety and its relationship with social phobia and dimensions of perfectionism. Research Studies in Music Education. Doi: 10.1177/1321103X18804295

Doruyter, A., Dupont, P., Stein, D. J., Lochner, C., \& Warwick, J.M. (2018). Nuclear neuroimaging in social anxiety disorder: a review. Journal of Nuclear Medicine, 59(12), 1794-1800.

Du Rocher, A.R., \& Pickering, A.D. (2019). The effects of social anxiety on emotional face discrimination and its modulation by mouth salience. Cognition and Emotion, 33(4), 832839.

Dunkley, D.M., Blankstein, K.R., Zuroff, D.C., Lecce, S., \& Hui, D. (2006). Self-critical and personal standards factors of perfectionism located within the five-factor model of personality. Personality and Individual Differences, 40(3), 409-420.

Dunkley, D.M., Zuroff, D.C., \& Blankstein, K.R. (2003). Self-critical perfectionism and daily affect: Dispositional and situational influences on stress and coping. Journal of Personality and Social Psychology, 84(1), 234-252.

Eaton, W.W., Bienvenu, O.J., \& Miloyan, B. (2018). Specific phobias. The Lancet Psychiatry, $5(8), 678-686$.

Ericsson, K.A. (1997). Deliberate practice and the acquisition of expert performance: an overview. In H. Jørgensen, \& A.C. Lehmann (Eds.), Does practice make perfect? Current theory and research on instrumental music practice (9-51). Oslo: Norwegian State Academy of Music

Essau, C.A., Lewinsohn, P.M., Lim, J.X., Ho, M.R., \& Rohde, P. (2018). Incidence, recurrence and comorbidity of anxiety disorders in four major developmental stages. Journal of Affective Disorders, 228, 248-253.

Eysenck, M.W. (1997). Anxiety and cognition: A unified theory. Hove, UK: Psychology

Farnsworth-Grodd, V.A. (2012). Mindfulness and the self-regulation of music performance anxiety. Masters theses. University of Auckland. Letöltve: 2019. 03. 08-án: https:/ / researchspace. auckland.ac.nz/handle/2292/19993

Fehér, O., \& Kasik, L. (2018). A szociálisprobléma-megoldás és a perfekcionizmus kapcsolata 12, 15 és 18 évesek körében. Iskolakultúra, 28(8-9), 9-21. 
Fehm, L., \& Schmidt, K. (2006). Performance anxiety in gifted adolescent musicians. Journal of Anxiety Disorders, 20(1), 98-109.

Fishbein, M., Middlestadt, S.E., Ottati, V., Straus, S., \& Ellis, A. (1988). Medical problems among ICSOM musicians: Overview of a national survey. Medical Problems of Performing Artists, 3(1), 1-8.

Flett, G.L., Hewitt, P.L., Blankstein, K., \& Gray, L. (1998). Psychological distress and the frequency of perfectionistic thinking. Journal of Personality and Social Psychology, 75(5), 1363-1381.

Flett, G.L., Hewitt, P.L., Oliver, J.M., \& Macdonald, S. (2002). Perfectionism in children and their parents: A developmental analysis. In G.L. Flett, \& P.L. Hewitt (Eds.), Perfectionism: Theory, research, and treatment (89-132). Washington, DC: American Psychological Association

Frost, R.O., Heimberg, R.G., Holt, C.S., Mattia, J.I., \& Neubauer, A.L. (1993). A comparison of two measures of perfectionism. Personality and Individual Differences, 14(1), 119-126.

Frost, R.O., Marten, P., Lahart, C., \& Rosenblate, R. (1990). The dimensions of perfectionism. Cognitive Therapy and Research, 14(5), 449-468.

Goldin, P.R., \& Gross, J.J. (2010). Effects of mindfulness-based stress reduction (MBSR) on emotion regulation in social anxiety disorder. Emotion, 10(1), 83-91.

González, A., Blanco-Piñeiro, P., \& Díaz-Pereira, M.P. (2017). Music performance anxiety: Exploring structural relations with self-efficacy, boost, and self-rated performance. Psychology of Music, 46(6), 831-847.

Gorges, S., Alpers, G. W., \& Pauli, P. (2007). Musical performance anxiety as a form of social anxiety? International Symposium on Performance Science, 1, 67-72.

Gouze, K.R., Hopkins, J., Bryant, F.B., \& Lavigne, J.V. (2016). Parenting and anxiety: Bidirectional relations in young children. Journal of Abnormal Child Psychology, 45(6), 1169-1180.

Grant, B.F., Goldstein, R.B., Saha, T.D., Chou, S.P., Jung, J., Zhang, H., et al. (2015). Epidemiology of DSM-5 alcohol use disorder: Results from the National Epidemiologic Survey on Alcohol and Related Conditions III. JAMA Psychiatry, 72(8), 757-766.

Green, J.G., McLaughlin, K.A., Berglund, P.A., Gruber, M.J., Sampson, N.A., Zaslavsky, A.M., et al. (2010). Childhood adversities and adult psychiatric disorders in the National Comorbidity Survey Replication I. Archives of General Psychiatry, 67(2), 113.

Grégoire, S., Lachance, L., Bouffard, T., \& Dionne, F. (2018). The use of acceptance and commitment therapy to promote mental health and school engagement in university students: A multisite randomized controlled trial. Behavior Therapy, 49(3), 360-372.

Gregory, B., \& Peters, L. (2017). Changes in the self during cognitive behavioural therapy for social anxiety disorder: A systematic review. Clinical Psychology Review, 52, 1-18.

Hamachek, D.E. (1978). Psychodynamics of normal and neurotic perfectionism. A Journal of Human Behavior, 15(1), 27-33.

Hayes, S.C. (2004). Acceptance and commitment therapy and the new behavioral therapies: Mindfulness, acceptance, and relationship. In S.C. Hayes, V.M., Follette, \& M.M. Linehan (Eds.), Mindfulness and acceptance: Expanding the cognitive behavioral tradition (1-29). New York, NY: Guilford Press

Hendricks, K.S. (2014). Changes in self-efficacy beliefs over time: Contextual influences of gender, rank-based placement, and social support in a competitive orchestra environment. Psychology of Music, 42(3), 347-365.

Hewitt, P.L., Flett, G.L., Sherry, S.B., Habke, M., Parkin, M., Lam, R.W., et al. (2003). The inter-personal expression of perfection: Perfectionistic self-presentation and psychological distress. Journal of Personality and Social Psychology, 84(6), 1303-1325. 
Hoge, E.A., Bui, E., Palitz, S.A., Schwarz, N.R., Owens, M.E., Johnston, et al. (2018). The effect of mindfulness meditation training on biological acute stress responses in generalized anxiety disorder. Psychiatry Research, 262, 328-332.

Hong, R.Y., Lee, S.S.M., Chng, R.Y., Zhou, Y., Tsai, F.-F., \& Tan, S.H. (2016). Developmental trajectories of maladaptive perfectionism in middle childhood. Journal of Personality, 85(3), 409-422.

Hughes, M.E., Mohatt, J., Bennett, S.M., \& Walkup, J.T. (2015). Anxiety disorder in youth: separation anxiety, social anxiety, and generalized anxiety disorders. In A. Tasman, J. Kay, J.A. Lieberman, M.B. First, M.B. Riba (Eds.), Psychiatry, Vol. 1, 4 $4^{\text {th }}$ ed.(1007-1018). Hoboken, NJ: Wiley-Blackwell

Iñesta, C., Terrados, N., García, D., \& Pérez, J.A. (2008). Heart rate in professional musicians. Journal of Occupational Medicine and Toxicology, 3(1), 16. Doi:10.1186/1745-6673-3-16

Iuscaa, D., \& Dafinoiu, I. (2012). Performance anxiety and musical level of undergraduate students in exam situations: The role of gender and musical instrument. Procedia-Social and Behavioral Sciences, 33, 448-452.

Jacobson, N.C., \& Newman, M.G. (2017). Anxiety and depression as bidirectional risk factors for one another: A meta-analysis of longitudinal studies. Psychological Bulletin, 143(11), 1155-1200.

James, I., \& Savage, I. (1984). Beneficial effect of nadolol on anxiety-induced disturbances of performance in musicians: A comparison with diazepam and placebo. American Heart Journal, 108(4), 1150-1155.

James, K.M., Owens, M., Woody, M.L., Hall, N.T., \& Gibb, B.E. (2018). Parental expressed emotion-criticism and neural markers of sustained attention to emotional faces in children. Journal of Clinical Child \& Adolescent Psychology, 1-10.

Jensen, S.N., Ivarsson, A., Fallby, J., Dankers, S., \& Elbe, A.-M. (2018). Depression in Danish and Swedish elite football players and its relation to perfectionism and anxiety. Psychology of Sport and Exercise, 36, 147-155.

Juncos, D.G., Heinrichs, G.A., Towle, P., Duffy, K., Grand, S.M., Morgan, M.C., et al. (2017). Acceptance and Commitment Therapy for the treatment of music performance anxiety: a pilot study with student vocalists. Frontiers in Psychology, 8, 986 Doi:10.3389/ fpsyg.2017.00986

Juncos, D.G., \& de Paiva e Pona, E. (2018). Acceptance and commitment therapy as a clinical anxiety treatment and performance enhancement program for musicians. Music and Science, 1, 1-17.

Juncos, D.G., \& Markman, E.J. (2016). Acceptance and commitment therapy for the treatment of music performance anxiety: A single subject design with a university student. Psychology of Music, 44(5), 935-952.

Kaiseler, M., Levy, A., Nicholls, A.R., \& Madigan, D.J. (2017). The independent and interactive effects of the Big-Five personality dimensions upon dispositional coping and coping effectiveness in sport. International Journal of Sport and Exercise Psychology. Doi:1 $0.1080 / 1612197 x .2017 .1362459$

Kaleńska-Rodzaj, J. (2018).Waiting for the concert. Pre-performance emotions and the performance success of teenage music school students. Polish Psychological Bulletin, 49(3), 322-331.

Kardum, I., \& Krapić, N. (2001). Personality traits, stressful life events, and coping styles in early adolescence. Personality and Individual Differences, 30(3), 503-515.

Kaspersen, M., \& Goetestam, G. (2002). A survey of music performance anxiety among norwegian music students. European Journal of Psychiatry, 16(69-80). 
Kenny, D., Driscoll, T., \& Ackermann, B. (2012). Psychological well-being in professional orchestral musicians in Australia: A descriptive population study. Psychology of Music, $42(2), 210-232$.

Kenny, D.T. (2004). Music performance anxiety: is it the music, the performance or the anxiety? Music Forum, 10(4), 38-43.

Kenny, D.T. (2006). Music performance anxiety: Origins, phenomenology, assessment and treatment. Context: Journal of Music Research, 31, 51-64.

Kenny, D.T. (2010). Negative emotions in music making: Performance anxiety. In P. Juslin, \& J. Sloboda (Eds.), Handbook of music and emotion: Theory, research, applications (425-451). Oxford, UK: Oxford University Press

Khalsa, S.B.S., \& Cope, S. (2006). Effects of a yoga lifestyle intervention on performancerelated characteristics of musicians: a preliminary study. Medical Science Monitor, 12, 325-331.

Khalsa, S.B.S., Butzer, B., Shorter, S.M., Reinhardt, K.M., \& Cope, S. (2013). Yoga reduces performance anxiety in adolescent musicians. Alternative Therapies in Health and Medicine, 19(2), 34-45.

Klibert, J., Lamis, D.A., Naufel, K., Yancey, C.T., \& Lohr, S. (2015). Associations between perfectionism and generalized anxiety: examining cognitive schemas and gender. Journal of Rational-Emotive and Cognitive-Behavior Therapy, 33(2), 160-178.

Kobori, O., Yoshie, M., Kudo, K., \& Ohtsuki, T. (2011). Traits and cognitions of perfectionism and their relation with coping style, effort, achievement, and performance anxiety in Japanese musicians. Journal of Anxiety Disorders, 25(5), 674-679.

Kochel, K.P., Bagwell, C.L., Ladd, G.W., \& Rudolph, K.D. (2017). Do positive peer relations mitigate transactions between depressive symptoms and peer victimization in adolescence? Journal of Applied Developmental Psychology, 51, 44-54.

Koyuncu, A., Ertekin, E., Deveci, E., Ertekin, B.A., Yuksel, Ç., Qelebi, F., et al. (2015). Age of onset in social anxiety disorder: Relation to clinical variables and major depression comorbidity. Annals of Clinical Psychiatry, 27(2), 84-89.

Lake, R.I.E., Eaves, L.J., Maes, H.H.M., Heath, A.C., \& Martin, N.G. (2000). Further evidence against the environmental transmission of individual differences in neuroticism from a collaborative study of 45,850 twins and relatives on two continents. Behavior Genetics, 30(3), 223-233.

Langendörfer, F., Hodapp, V., Kreutz, G., \& Bongard, S. (2006). Personality and performance anxiety among professional orchestra musicians. Journal of Individual Differences, 27(3), 162-171.

Langer, J.K., Tonge, N.A., Piccirillo, M., Rodebaugh, T.L., Thompson, R.J., \& Gotlib, I.H. (2019). Symptoms of social anxiety disorder and major depressive disorder: A network perspective. Journal of Affective Disorders, 243, 531-538.

LeBlanc, A., Jin, Y.C., Obert, M., \& Siivola, C. (1997). Effect of audience on music performance anxiety. Journal of Research in Music Education, 45(3), 480-496.

Lederman, R.J. (1999). Medical treatment of performance anxiety. Medical Problems of Performing Artists, 14(3),117-121.

Lee, W., Lee, M.-J., \& Bong, M. (2014). Testing interest and self-efficacy as predictors of academic self-regulation and achievement. Contemporary Educational Psychology, 39(2), 86-99.

Lewinsohn, P.M., Holm-Denoma, J.M., Small, J.W., Seeley, J.R., \& Joiner, T.E. (2008). Separation anxiety disorder in childhood as a risk factor for future mental illness. Journal of the American Academy of Child and Adolescent Psychiatry, 47(5), 548-555. 
Li, L., Wu, C., Gan, Y., Qu, X., \& Lu, Z. (2016). Insomnia and the risk of depression: a metaanalysis of prospective cohort studies. BMC Psychiatry, 16(1). Doi: 10.1186/s12888-0161075-3

Lieb, R., Wittchen, H.-U., Höfler, M., Fuetsch, M., Stein, M.B., \& Merikangas, K.R. (2000). Parental psychopathology, parenting styles, and the risk of social phobia in offspring. Archives of General Psychiatry, 57(9), 859-866.

Limburg, K., Watson, H.J., Hagger, M.S., \& Egan, S.J. (2016). The relationship between perfectionism and psychopathology: A meta-analysis. Journal of Clinical Psychology, 73(10), 1301-1326.

Maldonado, L., Huang, Y., Chen, R., Kasen, S., Cohen, P., \& Chen, H. (2013). Impact of early adolescent anxiety disorders on self-esteem development from adolescence to young adulthood. Journal of Adolescent Health, 53(2), 287-292.

McPherson, G.E., \& Davidson, J.W. (2002). Musical practice: Mother and child interactions during the first year of learning an instrument. Music Education Research, 4(1), 141-156.

McPherson, G.E., \& Davidson, J.W. (2006). Playing an instrument. In G.E. McPherson (Ed.), The child as musician: a handbook of musical development (331-351). Oxford: Oxford University Press

McPherson, G.E., \& McCormick, J. (2006). Self-efficacy and music performance. Psychology of Music, 34(3), 322-336.

McPherson, G.E., Osborne, M.S., Evans, P., \& Miksza, P. (2019). Applying self-regulated learning microanalysis to study musicians' practice. Psychology of Music, 47(1), 18-32.

Meyer, A.L., \& Kroner, H.B. (2017). The prediction of clinically relevant anxiety symptoms in early adulthood: Direct and indirect effects of childhood and parental factors. Journal of Depression and Anxiety, 6(2).

Miller, J.J., Fletcher, K., \& Kabat-Zinn, J. (1995). Three-year follow-up and clinical implications of a mindfulness meditation-based stress reduction intervention in the treatment of anxiety disorders. General Hospital Psychiatry, 17(3), 192-200.

Minarik, M.L., \& Ahrens, A.H. (1996). Relations of eating behavior and symptoms of depression and anxiety to the dimensions of perfectionism among undergraduate women. Cognitive Therapy and Research, 20(2), 155-169.

Mor, S., Day, H.I., Gordon, L., \& Hewitt, P.L. (1995). Perfectionism, control, and components of performance anxiety in professional artists. Cognitive Therapy and Research, 19(2), 207-225.

Moser, J.S., Slane, J.D., Burt, S.A., \& Klump, K.L. (2011). Etiologic relationships between anxiety and dimensions of maladaptive perfectionismin young adult female twins. Depression and Anxiety, 29(1), 47-53.

Nes, L.S., \& Segerstrom, S.C. (2006). Dispositional optimism and coping: a meta-analytic review. Personality and Social Psychology Review, 10(3), 235-251.

Newby, J.M., McKinnon, A., Kuyken, W., Gilbody, S., \& Dalgleish, T. (2015). Systematic review and meta-analysis of transdiagnostic psychological treatments for anxiety and depressive disorders in adulthood. Clinical Psychology Review, 40, 91-110.

Nicholson, D.R., Cody, M.W., \& Beck, J.G. (2014). Anxiety in musicians: On and off stage. Psychology of Music, 43(3), 438-449.

Nielsen, C., Studer, R.K., Hildebrandt, H., Nater, U.M., Wild, P., Danuser, B., et al. (2017). The relationship between music performance anxiety, subjective performance quality and post-event rumination among music students. Psychology of Music, 46(1), 136-152.

Nielsen, S.G. (2004). Strategies and self-efficacy beliefs in instrumental and vocal individual practice: a study of students in higher music education. Psychology of Music, 32(4), 418431. 
Nubé, J. (1991). Beta-blockers: Effects on performing musicians. Medical Problems of Performing Artists, 6, 61-68.

Nusseck, M., Zander, M., \& Spahn, C. (2015). Music performance anxiety in young musicians: comparison of playing classical or popular music. Medical Problems of Performing Artists, 30(1), 30-37.

Oddo-Sommerfeld, S., Hain, S., Louwen, F., \& Schermelleh-Engel, F. (2015). Longitudinal effects of dysfunctional perfectionism and avoidant personality style on postpartum mental disorders: Pathways through antepartum depression and anxiety. Journal of Affective Disorders, 191, 280-288.

Orejudo Hernández, S., Zarza-Alzugaray, F.J., \& Casanova, O. (2018). Music performance anxiety. Substance use and career abandonment in Spanish music students. International Journal of Music Education, 36(3), 460-472.

Orejudo, S., Zarza-Alzugaray, F.J., Casanova, O., Rodríguez-Ledo, C., \& Mazas, B. (2016). The relation of music performance anxiety (MPA) to optimism, self-efficacy, and sensitivity to reward and punishment: Testing Barlow's theory of personal vulnerability on a sample of Spanish music students. Psychology of Music, 45(4), 570-583.

Osborne, M.S., \& Kenny, D.T. (2005). Development and validation of a music performance anxiety inventory for gifted adolescent musicians. Journal of Anxiety Disorders, 19(7), 725-751.

Osborne, M.S., Greene, D.J., \& Immel, D.T. (2014). Managing performance anxiety and improving mental skills in conservatoire students through performance psychology training: A pilot study. Psychology of Well-Being, 4(18), 1-17.

Osborne, M.S., Kenny, D.T., \& Holsomback, R. (2005): Assessment of music performance anxiety in late childhood: A validation study of the music performance anxiety inventory for adolescents (MPAI-A). International Journal of Stress Management, 12(4), 312-330.

Osório, F.L., Sabino, A.D., \& Camargo, C.M. (2017). Could deficits in the recognition of emotions that indicate social approval be associated with musical performance anxiety? European Psychiatry, 41, S109-S110.

Paliaukiene, V., Kazlauskas, E., Eimontas, J., \& Skeryte-Kazlauskiene, M. (2018). Music performance anxiety among students of the academy in Lithuania. Music Education Research, 20(3), 390-397.

Papageorgi, I., Creech, A., \& Welch, G. (2011). Perceived performance anxiety in advanced musicians specializing in different musical genres. Psychology of Music, 41(1), 18-41.

Patston, T., \& Loughlan, T. (2014). Playing with performance: The use and abuse of betablockers in the performing arts. Victorian Journal of Music Education, 1, 3-10.

Patston, T., \& Osborne, M.S. (2016). The developmental features of music performance anxiety and perfectionism in school age music students. Performance Enhancement $\mathcal{E}$ Health, 4(1-2), 42-49.

Perczel-Forintos, D., \& Kresznerits, Sz. (2017). Szociális szorongás és önértékelés: A „Félelem a negatív megítéléstől” (FÉLNE) kérdőív hazai adaptációja. Orvosi Hetilap, 158(22), 843-850.

Peyre, H., Hoertel, N., Rivollier, F., Landman, B., McMahon, K., Chevance, A., et al. (2016). Latent class analysis of the feared situations of social anxiety disorder: A populationbased study. Depression and Anxiety, 33(12), 1178-1187.

Piccirillo, M.L., Dryman, M.T., \& Heimberg, R.G. (2016). Safety behaviors in adults with social anxiety: review and future directions. Behavior Therapy, 47(5), 675-687.

Qudsyia, H., \& Putri, M.I. (2016). Self-efficacy and anxiety of national examination among high school students. Procedia - Social and Behavioural Sciences, 217, 268-275. 
Raeburn, S.D., Hipple, J., Delaney, W., \& Chesky, K. (2003). Surveying popular musicians' health status using convenience samples. Medical Problems of Performing Arts, 18(3), 113-119.

Raknes, S., Pallesen, S., Bjaastad, J.F., Wergeland, G.J., Hoffart, A., Dyregrov, K., et al. (2017). Negative life events, social support, and self-efficacy in anxious adolescents. Psychological Reports, 120(4), 609-626.

Ritchie, L., \& Williamon, A. (2010). Measuring distinct types of musical self-efficacy. Psychology of Music, 39(3), 328-344.

Robson, K.E., \& Kenny, D.T. (2017). Music performance anxiety in ensemble rehearsals and concerts: A comparison of music and non-music major undergraduate musicians. Psychology of Music, 45(6), 868-885.

Rodebaugh, T.L., \& Chambless, D.L. (2004). Cognitive therapy for performance anxiety. Journal of Clinical Psychology, 60(8), 809-820.

Rodríguez-Carvajal, R., Lecuona, O., Vilte, L.-S., Moreno-Jiménez, J., \& de Rivas, S. (2017). Freeing the performer's mind: A structural exploration of how mindfulness influences music performance anxiety, negative affect and self-consciousness among musicians. Doi: 10.31231/osf.io/657n8. Letöltve: 2019. 03. 07-én: https://mindrxiv.org/657n8/

Rosenthal, P. (2000). Inderal for performance anxiety: Better living through chemistry or bargaining with Satan? The Horn Call - Journal of the International Horn Society, 30(3), 67-73.

Ruscio, A.M., Brown, T.A., Chiu, W.T., Sareen, J., Stein, M.B., \& Kessler, R.C. (2007). Social fears and social phobia in the USA: results from the National Comorbidity Survey Replication. Psychological Medicine, 38(1), 15-28.

Ryan, C. (1998). Exploring musical performance anxiety in children. Medical Problems of Performing Artists 13(3), 83-88.

Ryan, C. (2004). Gender differences in children's experience of musical performance anxiety. Psychology of Music, 32(1), 89-103.

Ryan, C. (2005). Experience of musical performance anxiety in elementary school children. International Journal of Stress Management, 12(4), 331-342.

Ryan, C., \& Andrews, N. (2009). An investigation into the choral singer's experience of music performance anxiety. Journal of Research in Music Education, 57(2), 108-126.

Sabino, A.D.V., Camargo, C.M., Chagas, M.H.N., \& Osório, F.L. (2018). Facial recognition of happiness is impaired in musicians with high music performance anxiety. Frontiers in Psychiatry, 9, 1-5.

Salmon, P.G. (1990). A psychological perspective on musical performance anxiety: A review of the literature. Medical Problems of Performing Artists, 5(1), 2-11.

Schalkwijk, F., Van Someren, E.J.W., \& Wassing, R. (2019). A clinical interpretation of shame regulation in maladaptive perfectionism. Personality and Individual Differences, 138, 19-23.

Scheier, M.F., \& Carver, C.S. (1985). Optimism, coping, and health: Assessment and implications of generalized outcome expectancies. Health Psychology, 4, 219-247.

Schink, T., Kreutz, G., Busch, V., Pigeot, I., \& Ahrens, W. (2014). Incidence and relative risk of hearing disorders in professional musicians. Occupational and Environmental Medicine, 71(7), 472-476.

Schmidt, R.E., Courvoisier, D.S., Cullati, S., Kraehenmann, R., \&Van der Linden, M. (2018). Too imperfect to fall asleep: perfectionism, pre-sleep counterfactual processing, and insomnia. Frontiers in Psychology, 9, 1288 Doi: 10.3389/fpsyg.2018.01288

Shafran, R., Cooper, Z., \& Fairburn, C.G. (2002). Clinical perfectionism: a cognitivebehavioural analysis. Behaviour Research and Therapy,40(7), 773-791. 
Shapero, B.G., Greenberg, J., Mischoulon, D., Pedrelli, P., Meade, K., \& Lazar, S.W. (2018). Mindfulness-based cognitive therapy improves cognitive functioning and flexibility among individuals with elevated depressive symptoms. Mindfulness, 9(5), 1457-1469.

Sinden, L.M. (1999). Music performance anxiety: Contributions of perfectionism, coping style, self-efficacy, and self-esteem. PhD Thesis. Arizona State University. Dissertation Abstracts International Section A: Humanities and Social Sciences, 60(3-A), 0590.

Smalley S.L., \& Winston, D. (2010). Fully present: The science, art, and practice of mindfulness. Boston, MA: Da Capo Press

Smith, A.J., \& Rickard, N.S. (2004). Prediction of music performance anxiety via personality and trait anxiety in young musicians. Australian Journal of Music Education, 1, 3-12.

Smith, M.M., Saklofske, D.H., Yan, G., \& Sherry, S.B. (2017). Does perfectionism predict depression, anxiety, stress, and life satisfaction after controlling for neuroticism? Journal of Individual Differences, 38(2), 63-70.

Smith, M.M., Sherry, S.B., McLarnon, M.E., Flett, G.L., Hewitt, P.L., Saklofske, D.H., et al. (2018). Why does socially prescribed perfectionism place people at risk for depression? A five-month, two-wave longitudinal study of the Perfectionism Social Disconnection Model. Personality and Individual Differences, 134, 49-54.

Smith, M.M., Sherry, S.B., Mushquash, A.R., Saklofske, D.H., Gautreau, C.M., \& Nealis, L.J. (2017). Perfectionism erodes social self-esteem and generates depressive symptoms: Studying mother-daughter dyads using a daily diary design with longitudinal followup. Journal of Research in Personality, 71, 72-79.

Spielberger, C.D., Gonzalez-Reigosa, F., Martinez-Arratia, A., Natalicio, L.F.S., \& Natalicio, D.S. (1971). Development of the Spanish edition of the state-trait anxiety inventory. Interamerican Journal of Psychology, 5, 145-158.

Spijkerman, M.P.J., Pots, W.T.M., \& Bohlmeijer, E.T. (2016). Effectiveness of online mindfulness-based interventions in improving mental health: A review and metaanalysis of randomised controlled trials. Clinical Psychology Review, 45, 102-114.

Stein, D.J., Lim, C.C.W., Roest, A.M., de Jonge, P., Aguilar-Gaxiola, S., Al-Hamzawi, A., et al. (2017). The cross-national epidemiology of social anxiety disorder: data from the world mental health survey initiative. BMC Medicine, 15(1): 143. Doi: 10.1186/s12916017-0889-2

Steptoe, A., \& Fidler, H. (1987). Stage fright in orchestral musicians: A study of cognitive and behavioural strategies in performance anxiety. British Journal of Psychology, 78(2), 241-249.

Stevens, S., Cooper, R., Bantin, T., Hermann, C., \& Gerlach, A.L. (2017). Feeling safe but appearing anxious: Differential effects of alcohol on anxiety and social performance in individuals with social anxiety disorder. Behaviour Research and Therapy, 94, 9-18.

Stoeber, J., Madigan, D.J., Damian, L.E., Esposito, R.M., \& Lombardo, C. (2016). Perfectionism and eating disorder symptoms in female university students: The central role of perfectionistic self-presentation. Eating and Weight Disorders - Studies on Anorexia, Bulimia and Obesity, 22(4), 641-648.

Talsma, K., Schüz, B., Schwarzer, R., \& Norris, K. (2018). I believe, therefore I achieve (and vice versa): A meta-analytic cross-lagged panel analysis of self-efficacy and academic performance. Learning and Individual Differences, 61, 136-150.

Terry-Short, L.A., Owens, R.G., Slade, P.D., \& Dewey, M.E. (1995). Positive and negative perfectionism. Personality and Individual Differences, 18(5), 663-668.

Thomas, J.P., \& Nettelbeck, T. (2013). Performance anxiety in adolescent musicians. Psychology of Music, 42(4), 624-634. 
Topoğlu, O., Karagülle, D., Keskin, T., Abacigil, F., \& Okyay, P. (2018). General health status, music performance anxiety, and coping methods of musicians working in turkish state symphony orchestras: A cross-sectional study. Medical Problems of Performing Artists, 33(2), 118-123.

Torro-Alves, N., Bezerra, I.A. de O., Claudino, R.G.e, Rodrigues, M.R., Machado-de-Sousa, J P., Osório, F. de L., et al. (2016). Facial emotion recognition in social anxiety: The influence of dynamic information. Psychology and Neuroscience, 9(1), 1-11.

Vaag, J., Bjørngaard, J.H., \& Bjerkeset, O. (2015). Symptoms of anxiety and depression among Norwegian musicians compared to the general workforce. Psychology of Music, 44(2), 234-248.

Vaillancourt, T., \& Haltigan, J.D. (2018). Joint trajectories of depression and perfectionism across adolescence and childhood risk factors. Development and Psychopathology, 30(2), 461-477.

Varga, M., \& Babusa, B. (2012). Az új keletú evészavarok néhány pszichológiai és rendszerszemléleti vonatkozása. Lege Artis Medicinae, 22(6-7), 440-444.

Vink, D., Aartsen, M.J., \& Schoevers, R.A. (2008). Risk factors for anxiety and depression in the elderly: A review. Journal of Affective Disorders, 106(1-2), 29-44.

Viskovich, S., \& Pakenham, K.I. (2018). Pilot evaluation of a web-based acceptance and commitment therapy program to promote mental health skills in university students. Journal of Clinical Psychology, 74(12), 2047-2069.

Wang, Z., Whiteside, S.P.H., Sim, L., Farah, W., Morrow, A.S., Alsawas, M., et al. (2017). Comparative effectiveness and safety of cognitive behavioral therapy and pharmacotherapy for childhood anxiety disorders. JAMA Pediatrics, 171(11), 1049-1056.

Wigfield, A., \& Eccles, J. (1994). Children's comptence beliefs, achievement values, and general self-esteem - Change across elementary and middle school. Journal of Early Adolescence, 14(2), 107-138.

Wijsman, S., \& Ackermann, B.J. (2018). Educating Australian musicians: are we playing it safe? Health Promotion International. Doi:10.1093/heapro/day030

Williamon, A., Aufegger, L., \& Eiholzer, H. (2014). Simulating and stimulating performance: Introducing distributed simulation to enhance musical learning and performance. Frontiers in Psychology, 5(25), 1-9.

Winnebeck, E., Fissler, M., Gärtner, M., Chadwick, P., \& Barnhofer, T. (2017). Brief training in mindfulness meditation reduces symptoms in patients with a chronic or recurrent lifetime history of depression: A randomized controlled study. Behaviour Research and Therapy, 99, 124-130.

Woody, R., \& McPherson, G. (2010). Emotion and motivation in the lives of performers. In P.N. Juslin, \& J.A. Sloboda (Eds.), Handbook of music and emotion: Theory, research, applications (401-424). Oxford, UK: Oxford University Press

Young, L.N., Winner, E., \& Cordes, S. (2013). Heightened incidence of depressive symptoms in adolescents involved in the arts. Psychology of Aesthetics, Creativity, and the Arts, 7(2), 197-202.

Zakaria, J.B., Musib, H.B., \& Shariff, S.M. (2013). Overcoming performance anxiety among music undergraduates. Procedia - Social and Behavioral Sciences, 90, 226-234.

Zarza-Alzugaray, F.J., Orejudo, S., Casanova, O., \& Aparicio-Moreno, L. (2017). Music Performance Anxiety in adolescence and early adulthood: Its relation with the age of onset in musical training. Psychology of Music, 46(1), 18-32. 


\title{
Köszönetnyilvánítás
}

Köszönöm doktori témavezetőmnek, Dr. Pikó Bettinának a kutatásom során nyújtott iránymutatást és segítséget.

\section{Nyilatkozat érdekütközésról}

A szerző ezúton kijelenti, hogy esetében nem állnak fenn érdekütközések.

\section{Music performance anxiety: prevalence, origins, related disorders and personality traits, and ways of treatment

\author{
DOBOS, BIANKA
}

\begin{abstract}
Lack of social interactions and poor social functions, low self-afficacy and therefore low life satisfaction are often related to anxiety disorders. Social anxiety is not only associated with trait anxiety and the perfectionistic strivings, but also with the absence of protective factors. Despite of it's prevalence across our country, teachers find it difficult to give advice about how to treat the symptoms. While dynamic interest can be observed across countries and the number of therapeutic interventions for music performance anxiety is growing, there are only a few scientific papers about this subject in Hungary. I would like to fill this gap by introducing the music performance anxiety and its background, related mental disorders and treatments, that have already been used among musicians. Literature review shows that MPA is a phenomena that affects different age groups and musical instrument groups. Symptoms show similarities with specific phobia, but the more social fears the more likely there is an underlying social anxiety. The development of performance anxiety starts with panic-like negative emotions that over time become associated with music performance through conditioning process. Protective factors are self-efficacy and trait mindfulness, lack of these traits can lead to perfectionism and depression. Treatment can be complex due to comorbid disorders, but chosing the right therapy and medication often brings a positive outcome. There is a huge need for educational institutions to offer courses and programmes targeting music skills to provide guidance and a deeper look into performance anxiety and its treatment.
\end{abstract}

Keywords: stage fright, music performance anxiety, social phobia, social anxiety disorder, perfectionism, self-efficacy

\footnotetext{
A cikk a Creative Commons Attribution 4.0 International License (https://creativecommons.org/ licenses/by/4.0/) feltételei szerint publikált Open Access közlemény, melynek szellemében a cikk bármilyen médiumban szabadon felhasználható, megosztható és újraközölhető, feltéve, hogy az eredeti szerző és a közlés helye, illetve a CC License linkje és az esetlegesen végrehajtott módosítások feltüntetésre kerülnek. (SID_1)
} 